\title{
GROF KARLO (KÁROLY) KHUEN-HÉDERVÁRY I HRVATI
}

Dr. sc. Ladislav Heka, izvanredni profesor

Pravni fakultet Sveučilišta u Szegedu
UDK: 929 Khuen-Hedervary, D.

94(497.5)

Ur.: 23. srpnja 2016.

Pr.: 8. studenoga 2016.

Izvorni znanstveni rad

\section{Sažetak}

Jedna od najpoznatijih osoba hrvatske povijesti svakako je ban Károly (Karlo, Dragutin) grof Khuen Héderváry koji spada u red najznačajnih $i$ najviše pozicioniranih osoba hrvatsko-ugarske povijesti. Bio je državnik koji je dva desetljeća obnašao bansku čast te u dva navrata i funkciju predsjednika ugarske vlade. Za razliku od svoga prethodnika baruna Josipa Jelačića kojemu je hrvatska historiografija zapamtila samo dobre osobine, grof Khuen Héderváry $u$ narodnoj svijesti ostao je zabilježen u izrazito negativnome svjetlu kao povijesna ličnost koja se zauzimala za odnarođivanje i za mađarizaciju. O njemu se često ne zna ništa drugo do li narečenih stereotipa koji baš i ne odgovaraju povijesnim činjenicama. Često se ističe da je on stranac, nametnut izvana (iz Mađarske), iako je odrastao i najveći dio života proživio u Hrvatskoj. Zauzimao se za održavanje ugarsko-hrvatske državne zajednice te je promicao suradnju $i$ suživot dvaju naroda, a prava Hrvatske zastupao je ne samo obnašajući funkciju bana, nego i kao kraljevski personal te ugarski prvi ministar.

U ovome uratku analiziramo političke prilike u Ugarskoj i Hrvatskoj u drugoj polovici 19. i početkom 20. stoljeća te prikazujemo stajališta grofa KhuenaHéderváryja o hrvatskome pitanju.

Ključne riječi: hrvatski ban i predsjednik ugarske vlade grof Karlo Khuen Héderváry, hrvatsko-ugarska državna zajednica, dualizam, nacionalno pitanje, rasprava o proračunu za 1904. godinu.

\section{TKO JE BIO GROF KÁROLY KHUEN-HÉDERVÁRY?}

Grof Károly Khuen-Héderváry de Hédervár (Hédervári gróf dr. KhuenHéderváry Károly, 1849.-1918.), mađarsko-hrvatski je političar i državnik koji je obnašao čast hrvatskoga bana (1883.-1903.) te u dva navrata predsjednika ugarske vlade (27. lipnja 1903.-3. studenoga 1903. i 17. siječnja 1910.-22. travnja 1912.). Naslov Héderváry i posjede Ozora, Tamási i Hédervár naslijedio je nakon smrti svoga rođaka grofa Hédera Viczaya od Hédervára, zadnjega člana loze Viczay. Grof Viczay je, naime, oporukom iz 1873. za svoga nasljednika imenovao najstarijega živućega 
sina grofa Antona Khuena Bélásija (dakle svoga sinovca Karla) uz uvjet da u svoje obiteljsko prezime unese i pridjevak Héderváry. Grof Karlo (Károly) Khuen Bélási je to i učinio te je u prosincu 1874. iz Beča dobio dozvolu za korištenje dvojnoga prezimena Khuen-Héderváry. Tako je postao prvi grof s tim prezimenom. Novi je obiteljski grb nastao spajanjem grbova narečenih dviju obitelji.

Odrastao je na obiteljskom posjedu u u Nuštru (po nekima je tamo i rođen), a zatim je studirao pravo u Zagrebu (bila je prava rijetkost da jedan grof studira u malenome Zagrebu) i Požunu. Poslije studija 1875. počeo je javnu i političku djelatnost kao parlamentarni zastupnik Jura (Győr) iz redova vladajuće Slobodarske stranke (Szabadelvü Párt, u hrvatskoj literaturi ju gdjekad nazivaju Liberalnom strankom) čiji je član bio sve do njezina ukidanja. Od 1882. bio je veliki župan jurske županije, a od 1883. hrvatski ban. Nakon dvadesetogodišnjega upravljanja Trojednom kraljevinom grof Károly Khuen-Héderváry 27. lipnja 1903. imenovan je za ministra predsjednika Ugarske vlade (poslije odstupa ministra predsjednika Kálmána Szélla), a ujedno je bio i ministar unutarnjih poslova te ministar za odnose s kraljem. ${ }^{1}$ Ovu je čast obnašao do 3. studenoga 1903. kada je odstupio. Ministar unutarnjih poslova bio je i u vladi grofa Istvána Tisze (3. ožujka 1904.-18. siječnja 1905.), a usto je bio i parlamentarni zastupnik Temišvara iz redova Slobodarske stranke (1904.1906.) i član Doma velikaša (1906.-1910.). Poslije toga je stanovito vrijeme živio na svome obiteljskom posjedu u Héderváru. No, ipak se vratio u politički život i to na vrh nakon što je 17. siječnja 1910. još jednom dobio mandat za sastav vlade (poslije pada Wekerleova kabineta), ali tada već kao kandidat Nacionalne stranke rada (Nemzeti Munkapárt), čiji je bio jedan od osnivača. Stranka je nastala na tragovima bivše Slobodarske stranke koja je prestala postojati 1906. godine. U drugom mandatu na vlasti je ostao dvije godine, prije nego što je 22. travnja 1912. morao odstupiti. Uz funkciju ugarskoga predsjednika vlade istodobno je obnašao i funkciju ministra unutarnjih poslova i ministra za odnose s kraljem te hrvatsko-slavonskodalmatinskoga ministra bez lisnice. Na temelju ovih funkcija vidljivo je kako je volio držati konce u svojim rukama, napose u pitanjima unutarnjih poslova, ali i odnosa s dvorom te s Hrvatskom. Sa svojim užim zavičajem ostao je u tijesnim vezama, među inim i kao počasni građanin Zagreba i Varaždina. Politikom se bavio sve do smrti. Zadnjih godina života bio je zastupnik budimpeštanskoga IV. okruga (1910.1918.), prvi kraljev povjerenik (kod krunidbe, obreda prijenosa krune, od 23. do 30. prosinca 1916.) i predsjednik Nacionalne stranke rada (1913.-1918.) Poslije završetka državničke karijere 6. svibnja 1915. izabran je za stalnoga člana Mađarske akademije znanosti. Umro je u Budimpešti 16. veljače 1918., a pokopan je u Héderváru 21. veljače 1918.

Grof Khuen-Héderváry od 6. rujna 1880. bio je u braku s groficom Margit Teleki (1860.-1922.), pripadnicom stare mađarske grofovske obitelji koja je rodbinski bila povezana s grofovima Széchenyi i Esterházy. U njihovome su braku rođeni sinovi Sándor Khuen-Héderváry (1881.-1946.) i Károly Khuen-Héderváry ml. (1888.1960.). Sándor je bio diplomat, a Károly (rođen u Zagrebu 1888.) predsjednik

1 Kenyeres, Ágnes (főszerk.): Magyar életrajzi lexikon I. (A-K). Akadémiai Kiadó. Budapest, 1967., str. 915. 
Državne poljoprivredne komore, član Doma velikaša, a poslije 1918. i bilježnik toga doma te čelnik mađarskih izviđača. No, niti jedan od njih dvojice nije imao djece, pa je Károlyevom smrću 1960. izumrla muška grana ove obitelji.

Premda je dakle, najveći dio života (pogotovo do odlaska u Budimpeštu 1903.) proveo u Hrvatskoj, ipak se u hrvatskoj historiografiji o njemu stotinjak godina govorilo kao o strancu. Zanimljivo je da su nejasni mnogi podatci iz banova životopisa, napose oni o mjestu rođenja. U nekim se banovim životopisima spominje da je rođen 23. svibnja 1849. u Nuštru, ali većina njih navodi da je rođen u gornjosilezijskom (austrijskom) kupalištu Gräfenbergu pored Freiwaldaua (danas Jasenik, Češka Republika). ${ }^{2}$ Neki autori tvrde da je Nuštar kao rodno mjesto naveden zato kako bi se pokazalo da je ban „domaći čovjek, a ne stranac”, (ban tomu nije proturječio), dok drugi kažu da je Gräfenberg izmišljen kao rodno mjesto kako bi se umirili Mađari koji su grofa doživljavali kao došljaka iz Hrvatske. ${ }^{3} \mathrm{~S}$ tim u svezi profesorica Mira Kolar Dimitrijević kaže da se $u$ Hrvatskoj desetljećima namjerno tajilo čak $i$ to da je rođen u Nuštru i da odlično govori hrvatski jezik. ${ }^{4} \mathrm{U}$ prilog tvrdnji da je rođen u Hrvatskoj mogla bi posvjedočiti i grofova izjava objavljena u ugarskome tisku uoči njegova preuzimanja banske funkcije kako mu je rodište tamo, a domovina ovdje, a oboje je jedna te ista zajednička domovina. ${ }^{5}$ Iz narečenoga je razvidno da se u nacionalnome pogledu ćutio Mađarom (premda je obitelj Khuen podrijetlom bila iz Tirola), a djetinjstvom (možda i rođenjem) bio je čvrsto vezan uz Hrvatsku (Slavoniju). Kao ban bio je legalist i legitimist, provodio je dosljedno Hrvatsko-ugarsku nagodbu i temeljna načela na kojima je počivala Dvojna monarhija. Premda su ga iz Mađarske u Hrvatsku ispratili uvjereni kako je premlad (u trenutku imenovanja banom imao je 34 godine), neiskusan i preslab da umiri uznemirenu Hrvatsku, a u Zagrebu su ga dočekali riječima da je „zimski ban” koji će vladati samo jednu zimu, ipak se pokazalo da je on vrlo umješan političar. U Ugarskoj se doskora - tragom napisa u hrvatskom tisku - proširilo da je ,pacificirao Hrvatsku”, a u Hrvatskoj je vladalo mišljenje da je „autokrat” te „eksponent Pešte koji provodi mađarizaciju. Nakon početnoga ushićenja njime, Mađari su mu sve više spočitavali da ne poduzima ništa da spriječi asimilaciju slavonskih Mađara, da se okružio zagovornicima hrvatske državnosti i protivnicima mađarske nacionalne ideje (riječ je o Josipu Pliveriću) ${ }^{6}$ te da se uz njegovo znanje $u$

2 Otac mu je bio grof Antun Leopold Khuen od Belása (1817.-1886.), a majka barunica Angelika Izdenczi od Monostora i Komlósa (1823.-1894.). Braća i sestre su mu: Zichy Zsigmondné Khuen Alice (1850.-1879.), Antal/Antun Khuen (1852.-1890.), Lordon-Laterano Albertné Khuen Angelika (1855.-1918.), Vay Tiborné Khuen Margit (1856.-1920.), Henrik Khuen (1860.-1928.) i Woracziczky Jánosné Khuen Szabina (1863.-1942.).

3 Ostajmer, Branko 2009. Khuen - ključna epizoda slavonskog regionalizma. U: Slavonija, Baranja i Srijem. Vrela europske civilizacije, sv. 1, ur. Božo Biškupić, Vesna Kusin, Branka Šulc, Zagreb, str. 390.-397., ovdje 391. str.

4 Kolar-Dimitrijević, Mira: Izidor Kršnjavi i simbolika zagrebačke Zlatne dvorane. U: Kolo, Zagreb, 2. 13. br. 5. http://www.matica.hr/kolo/401/Izidor\%20Kr\%C5\%A1njavi\%20i\%20 simbolika\%20zagreba\%C4\%8Dke\%20Zlatne\%20dvorane\%20 (10. lipnja 2016.).

5 Polić, Martin: Ban Dragutin grof Khuen-Héderváry i njegovo doba. Zagreb, 1901., str. 10.

6 Vidi opširnije: Holjevac, Željko: Pravo u službi nacionalnog pokreta: Josip Pliverić o pravnoj prirodi hrvatsko-ugarske 'državne zajednice' u doba dualizma. U: Marijana Marinović (ur.), Nacionalni pokret u Hrvatskoj u 19. stoljeću, Zagreb, 2008., str. 57-65. 
Hrvatskoj stvara jedna južnoslavenska država. I Hrvati i Mađari bili su složni samo u jednome: da je Khuen-Héderváry „kraljev čovjek”. To i jest bila istina, jer je on doista bio osoba od povjerenja Franje Josipa I. Uživajući kraljevu potporu usudio se usprotiviti i ugarskome ministru predsjedniku (premda je na njegov prijedlog i supotpis ban bio imenovan i razrješavan) kada je smatrao da su povrijeđena hrvatska prava. Željko Holjevac ističe kako „hrvatski ban nije javno dovodio u pitanje mnoge elemente hrvatske nagodbene posebnosti, ali je njegova promađarska politika u Hrvatskoj i Slavoniji bila dosljedna u službi čuvanja dualističke ravnoteže u AustroUgarskoj, pri čemu je Hrvatsko-ugarska nagodba kao ustavni dokument bila više nešto što se samo trpjelo nego nešto što se osobito promoviralo."

Po dolasku u Zagreb preuzeo je Narodnu stranku kojoj je uz pomoć hrvatskih Srba uspio osigurati saborsku većinu. No, po njegovu je odlasku u Budimpeštu ova stranka postala oporbena, a u Hrvatskoj više nije bilo političke opcije sklone uniji s Ugarskom. Grof je 1903. u Budimpešti dočekan s jednakim nepovjerenjem kao i dva desetljeća ranije u Zagrebu. Zbog toga si je u Mađarskoj - kao došljak iz Hrvatske morao prvo utemeljiti stranačku bazu. U njezinu nedostatku njegov prvi premijerski mandat (1903.) nije trajao dugo, dijelom i zbog parlamentarne opstrukcije kojoj je bio izložen, ali se drugi put (1910.-1912.) uspio održati čak dvije godine na vlasti što je u vrijeme teške političke krize u Ugarskoj bilo respektabilno.

Premda je tijekom cijele političke karijere bio osporavan, ipak je imao i mnoge pristaše, pa i prijatelje. Među njima je bilo i Hrvata koje je grof Khuen-Héderváry susljedno branio i puno godina nakon odlaska iz Hrvatske (primjerice Nikolu Tomašića koga je kao ugarski ministar predsjednik dao imenovati hrvatskim banom). Kontakte s Hrvatskom nikada nije prekidao (brat mu je živio u Nuštru) te je uvijek bio dobro informiran o političkim prilikama u ,posestrimi zemlji” s druge strane Drave. Drugi mađarski zastupnici često su imali poluinformacije o stanju u Trojednoj kraljevini, jer je poslije ukidanja latinskoga jezika kao službenoga, komunikacija između dva naroda postala otežana, pa su zbog nepoznavanja jezika druge strane Hrvati i Mađari sve manje znali jedni o drugima. Stoga se i dogodilo da su Mađari pogrešno procijenili stanje u Hrvatskoj, jer su bili uvjereni da su nagodbom zadovoljili sve hrvatske želje te da u Trojednici nerede doista pravi samo „grupa jugoslavenski orijentiranih oporbenjaka i hrvatskih nacionalista”. Do stanovitoga otrežnjenja došlo je zbog događaja 1883. godine („Dávidove ploče”) koji su teško uznemirili Mađare, a zatim su početak kraja državne zajednice nagovijestili događaji 1903. godine i nastanak Hrvatsko-srpske koalicije.

Drugom imenovanju ugarskim premijerom grofa Khuen-Héderváryja Srbi više nisu davali potporu, iako su ga svojedobno poštivali kao svoga zaštitnika od „velikohrvatskih težnja” i „srpskoga bana”. Nije mogao računati ni na Hrvate, kojima su samo nekoliko godina nakon velikih zagrebačkih prosvjeda odjednom Srbi postali bliski. Više nije bilo pritužaba da Srbi zauzimaju glavne funkcije u Hrvatskoj, jer su

7 Holjevac, Željko: Mađaroni i mađarizacija u Hrvatskoj između mita i zbilje u svjetlu hrvatskomađarskih odnosa u 19. stoljeću. U: Hrvati i manjine u Hrvatskoj: moderni identiteti. Četvrti hrvatski simpozij o nastavi povijesti. Agencija za odgoj i obrazovanje. Zagreb, 2014. http:// www.azoo.hr/images/izdanja/manjine/05.html (20. rujna 2016.). 
tada već i Hrvati pristali uz politiku koju je podupirao Beograd. Možemo zaključiti da ništa od banove politike nije ostalo osim hrvatsko-srpske pomirbe koju je od 1883 . promovirao.

Jedan od najboljih poznavatelja hrvatskih prilika prof. dr. József Bajza ${ }^{8}$ koji je prijateljevao s barunom Pavlom Rauchom, dakle Khuen-Héderváryjevim oponentom, u zbirci svojih publicističkih napisa objavljenoj pod naslovom $A$ horvát kérdés naziva grofa Khuena-Héderváryja najvećim hrvatskim političarom $u$ zadnjih pedeset godina. ${ }^{9}$ On je, dakako, iznio i kritičke opaske o banu napominjući da je jedna od žrtava njegova političkoga režima bio Ljubomir Babić iliti Ksaver Šandor Gjalski, čija je majka podrijetlom bila Mađarica (prezivala se Sándor što je pohrvaćeno u Šandor). Ističe da je Gjalski služio petnaestak godina kao upravni činovnik - pravnik, ali je jedva napredovao zbog svojih političkih stajališta. Bajza ga smatra najvećim i najobrazovanijim hrvatskim piscem koji je minuciozno prikazao sve slabosti i zloporabe banova režima te navodi da je grof Khuen-Héderváry jamačno čitao njegove radove, jer je neke novele osobno preporučio državnom odvjetništvu. ${ }^{10}$ Dodaje i da se u Hrvatskoj svaka anomalija banske vlasti ili u svezi s njom pripisivala Mađarima i Ugarskoj, pa je stoga razumljivo Babićevo protumađarsko stajalište. ${ }^{11}$

Iz današnje perspektive gledano možemo reći da u političkom smislu dvadesetogodišnje banovanje grofa Károlya Khuen-Héderváryja ostaje dvojbeno, ali je to bilo razdoblje svekolikoga gospodarskoga i kulturnoga razvitka Hrvatske. Zajedno s predstojnikom za bogoštovlje i nastavu (od 1891. do 1896.) Izidorom Kršnjavijem organizirao je gradnju škola i sakralnih objekata u cijeloj Hrvatskoj, inicirao bušenje arteških bunara u Dalmatinskoj zagori, što je omogućilo opstanak u tim krajevima, nadalje je organizirao veličanstvenu gospodarsku izložbu u Zagrebu 1891. godine. Osim toga za njegova banovanja Zagreb je posjetio kralj Franjo Josip I. Napose je zadužio hrvatsku prijestolnicu koju je od provincijskoga gradića pretvorio u pravi europski grad. ${ }^{12}$ Tada je obnovljena Zagrebačka katedrala, sagrađene su zgrada Hrvatskog narodnog kazališta, I. gimnazije (danas muzej Mimara), Škola

8 József Bajza (1885.-1938.) započeo je karijeru u budimpeštanskoj knjižnici Széchényi Könyvtár u kojoj se upoznao s mladim vježbenikom Milanom Šufflayem (Sufflay), hrvatsko-mađarskoj uniji bliskim povjesničarem koji je u narečenoj knjižnici radio od 1905. do 1908. te je uveliko utjecao na nešto mlađega Bajzu. Toliki da je Bajza počeo intenzivno učiti hrvatski jezik, te je 1923. izabran za profesora hrvatskoga jezika i književnosti na Sveučilištu Pázmány Péter Tudományegyetemen (preteči današnjega ELTE-e). Do smrti se bavio hrvatskom poviješću i književnošću održavajući prijateljske odnose sa Šuflajem, njegovim najboljim prijateljem Pavlom Rauchom i pravašem Ivom Frankom, poslije 1918. izbjeglicom u Budimpešti. Rauch je Bajzu prozvao „najhrvatskijim Mađarom”.

9 Bajza, József 1941. A horvát kérdés. Válogatott tanulmányok. Királyi Magyar Egyetemi Nyomda. Budapest, 1941., str. 251.

10 Isto.

11 Isto, str. 254.

12 Mađari su gdjekad ismijavali Hrvate da pokušavaju izjednačiti hrvatsku prijestolnicu s ugarskom. Razlika među njima bila je golema, jer je 1890. Budimpešta imala 486.671 stanovnika, a Zagreb 38.742 duša (dvanaest puta manje). U to je vrijeme primjerice Szeged imao 85.569 stanovnika, iliti dvostruko više žitelja od Zagreba, od kojega su veći broj stanovnika - pored županijskih središta - imali i neki mađarski provincijski gradići. 
za umjetnost i obrt (danas muzej), Umjetnički paviljon na Strossmayerovom trgu, zgrada Hrvatskog učiteljskog doma i učiteljska škola u Medulićevoj itd. Osnivane su banke, osiguravajuća društva, poljoprivredna udruženja, industrija se počela razvijati (tada su osnovane tvornica žigica Drava u Osijeku, tvornica kave Franck itd.), kao i poljoprivredna proizvodnja zahvaljujući kojoj su sagrađeni i parni mlinovi (među inim je takav mlin imao i banov brat Heinrich II. Jakob - Hinko u Nuštru), pivovare i tkaonice. Pored toga je počela elektrifikacija Hrvatske (veća mjesta su dobila javnu rasvjetu) te nagli razvoj željeznica.

\section{GROF KHUEN-HÉDERVÁRY I MAĐARIZACIJA}

Mađarska nacionalna politika državnoga jedinstva utemeljenoga na jednoj naciji i jednom jeziku doživjela je poraz 1848. kada su se nemađarski narodi u Ugarskoj okrenuli protiv mađarske borbe za neovisnost. Zbog toga su nakon oživljavanja ustavnoga života politički čelnici nastojali riješiti nacionalno pitanje. To je učinjeno Zakonom o nacionalnoj ravnopravnosti, broj 1868: XLIV. od 6. prosinca 1868. kojim je propisano: Svi državljani Ugarske na temelju osnovnih ustavnih načela u političkom pogledu čine jedan narod, nedjeljivi, jedinstveni mađarski narod, čiji ravnopravni član je svaki državljanin, neovisno od nacionalne pripadnosti. Odredbe toga zakona nisu se odnosile na Trojednu Kraljevinu, jer je njoj Hrvatsko-ugarskom nagodbom priznat poseban status, naime da je hrvatski narod poseban politički narod sa svojim posebnim teritorijem i autonomijom na području uprave, sudstva te prosvjete $\mathrm{i}$ bogoštovlja, kao i s hrvatskim službenim jezikom. ${ }^{13}$

Asimilatorska politika (ali i demografski porast) su za posljedicu imali porast broja Mađara unutar Habsburške Monarhije od 1850. do 1890. godine za oko 2,6 milijuna duša ili za 54 posto. Računa se da je u narečenom razdoblju pomađareno oko milijun ljudi, od kojih su jednu polovicu činili Židovi i drugi doseljenici, a drugu polovicu u Mađarskoj živuće autohtone nacionalnosti, poglavito Nijemci i Slovaci, te u nešto manjoj mjeri Hrvati (Bunjevci, Šokci i Hrvati iz zapadne Ugarske). Među nabrojenim narodima zabilježen je ne samo najveći broj pomađarenih, nego se $u$ njihovim redovima najbrže proveo postupak asimilicije. Jamačno je tomu pridonijela ista (katolička) vjeroispovijest (osim kod Židova), slične kulturne tradicije i običaji te zajednička višestoljetna povijest. Za razliku od navedenih, pomađarivanje Srba, Rumunja i Rusina bilo je malobrojno. Asimiliran je samo uzak krug plemstva, građanstva i inteligencije iz njihovih redova, jer je njih od Mađara razdvajala povijesna i kulturna raznolikost, vjerska i školska autonomija, konfesionalna raznolikost, život u izoliranim, zatvorenim sredinama itd. U njihove krajeve nije dopro ni kapitalistički razvoj, pa su skromne gospodarske prilike također utjecale na to da je izostala potreba da se integriraju u mađarsko društvo. Promatrajući motivacijske čimbenike prozlazi

13 §. 29. Odredbe ovoga zakona ne odnose se na Hrvatsku, Slavoniju i Dalmaciju, koje i čine posebnu političku naciju pogledu imaju poseban teritorij, nego su glede jezika za njih mjerodavne odredbe nagodbe koja je sklopljena između mađarskog sabora s jedne strane te hrvatskog sabora s druge strane. Na temelju iste zastupnici ovih zemalja na zajedničkom mađarsko-hrvatskom saboru imaju pravo koristiti svoj materinski jezik. 
da su se Nijemci i Židovi pomađarili zbog slabljenja ili nedostatka društvenih veza među njima, a Slovaci su se zbog nepovoljnih prirodnih datosti u velikom broju preselili u gradove gdje su oslabile tradicionalne veze, uključujući i nacionalne. Poznati istraživač Elek Fényes zabilježio je da se 1880. u 126 mađarskih gradova samo 47 posto stanovništva izjašnjavalo Mađarima, dok je po izračunu Pétera Hanáka 1910. godine njihov broj porastao na 70 posto. Najmanji broj Mađara zabilježen je od velikih gradova 1880. godine u Požunu $(15,7 \%)$, dok je trideset godina kasnije on porastao na čak 40,8 posto. U Temišvaru je 1880 bilo 20,4 posto Mađara, a 1910. 40,5 posto, u Sopronu 21,0 posto, a 1910. 43,0 posto, u Košicama 39,8 posto 1880. i čak 76,1 posto 1910. godine. Tijesnu natpolovičnu većinu su Mađari imali 1880. godine u Subotici (50,5\%), ali je u „bunjevačkoj prijestolnici” mađarizacija imala najmanji postotak porasta u usporedbi s drugim velikim gradovima. Naime, 1910. je u gradu bilo 58,6 posto Mađara. U Pečuhu je 1880. bilo 73,4 posto, a 1910. 83,9 posto Mađara, u Velikom Varadinu 1880. 86,8 posto, a 1910. 92,7 posto, u Juru (Györ) 1880. 92,8 posto, a 1910. 96,3 posto, te napokon u Segedinu 1880. 96,0 posto, a 1910. 96,3 posto mađarskoga pučanstva. Da je tendencija asimilacije bila vezana uz život u gradovima zorno potvrđuje primjer Pešte-Budima koji je potkraj 18. stoljeća imao 20 posto mađarskoga i 80 posto njemačkoga pučanstva. Njemački je bio govorni jezik, mađarski se jedva gdje čuo, a oko 70 posto peštanskih trgovaca bili su pravoslavni Grci. No, Mađari su potkraj 19. stoljeća činili već trećinu gradskoga stanovništva, a 1910. se stanovništvo grada povećalo za pet i pol puta te je udio Mađara porastao trinaest puta. Uoči Prvog svjetskog rata mađarska prijestolnica imala je 900000 stanovnika, od kojih se njih čak 86 posto izjasnilo Mađarima. Među milijun pomađarenih stanovnika Ugarske od 1880. do 1910. bilo je 400000 Nijemaca (njih 42 posto stiglo je iz provincijskih gradova i iz Banata), 280000 Slovaka, 190000 Židova, 80000 južnih Slavena (Bunjevaca, Šokaca, Hrvata uz nešto Slovenaca i Srba), 30000 Rumunja i 10000 Rusina. O stupnju asimilacije svjedoči podatak da je u mađarskoj prijestolnici 1880. godine 74 posto stanovnika govorilo njemački, a dvadeset godina kasnije samo njih 6,3 posto. Godine 1910. u zemlji je bilo više od 900.000 Židova od kojih se njih 700. 000 izjašnjavalo Mađarima. ${ }^{14}$

U Hrvatskoj mađarizacija nije imala ni približne razmjere gore navedenima, iako je opće mišljenje da je ona nasilno i sveobuhvatno provedena u „olovno” doba banovanja grofa Khuen-Héderváryja. U stvaranju javnoga mišljenja važnu su ulogu imale hrvatske novine uglavnom stranački obojene i sklone Narodnoj stranci. Naime, uniji s Ugarskom sklona Horvatsko-vugerska stranka (tzv. mađaroni) 1840-ih i njezina sljednica Narodna (i) ustavna stranka (tzv. unionisti) 1860-ih godina uopće nisu imale svoje glasilo u kojemu bi javnosti prezentirali svoja politička gledišta. To je bila velika pogreška, jer o snazi promidžbe iliraca protiv njihovih političkih protivnika svjedoči i Ante Starčević koji je u svojim uspomenama zapisao: Za Ilirstva nebiaše druga nego da budeš Ilir ili Magjaron. Reći da si Hrvat, znamenova da si Magjaron.

14 Ács, Zoltán: Nemzetiségek a történelmi Magyarországon. Az 1984-ben megjelent nemzetiségek a történelmi Magyarországon címü kötet átdologozott kiadása. Kossuth Könyvkiadó, 1996. http://www.sulinet.hu/oroksegtar/data/magyarorszagi_nemzetisegek/nemetek/ nemzetisegek_a_tortenelmi_magyarorszagon/pages/014_a_nemzetiseg_a_vilaghaboru_elott. htm (10. lipnja 2015.). 
Rodjen Magjar, rodjen u Ungarii, ter samo za vreme pribivajući u Hervatskoj ako si rekao da si Magjar, to je nosilo da si Magjaron. Samo u tu jednu stranku, u Ilire ili u Magjarone, morao je kod nas svatko spadati. O redkih koji se braniše proti tomu razredjivanju ljudih, ili nehtedoše u nijedan taj razred brojeni biti, o tih biaše sud da su habi-kruhi, prosvetljeni zvahu ih fruges consumere nati, a javno mnenje govoraše skladno, da su austrianski špioni. ${ }^{15}$ Horvatsko-vugerska stranka zauzimala se za modernizaciju Hrvatske izgradnjom željezničke pruge od Vukovara do Rijeke, za uvođenje slobode vjeroispovijesti i tiska, za učenje „diplomatičkoga” mađarskoga jezika u hrvatskim školama, kao i da hrvatske županije izravno biraju svoje nuncije u Ugarski sabor, kao što su to činile tri slavonske županije (budući da je većinski narodnjački Sabor birao i davao naputke nuncijima uglavnom iz svojih redova). ${ }^{16}$ Unionisti su svoj politički program otisnuli u svom prvom listu Hrvatskim novinama 10. i 11. prosinca 1867. godine u članku pod naslovom „Poštena unija“. U njemu su naglasili da se bore za četiri hrvatska cilja, naime, za narodnost, ustavnost, autonomiju i teritorijalnu cjelokupnost. ${ }^{17}$ Dakle, premda nedvojbeno hrvatski orijentirani tzv. unionisti su u hrvatskoj svijesti ostali upamćeni kao „mađaroni”, a Khuen- Héderváry kao provoditelj nasilne mađarizacije. Danas samo rijetki autori dovode u pitanje je li mađarizacije uopće bilo. ${ }^{18} \mathrm{~S}$ tim u vezi napominjemo da je Obzor u veljači 1873. godine pisao kako „ni u jednoj zemlji ne prodjoše osnove magjarizacije gore nego u Hrvatskoj “ ${ }^{19}$ Doista, podatci popisa stanovništva iz 1900. godine pokazuju da je u autonomnoj Hrvatskoj i Slavoniji mađarskim kao „državnim“ jezikom govorilo jedva 2,08 posto Hrvata (nekoliko desetljeća ranije doseljenih Mađara nastanjenih uglavnom u Slavoniji bilo je 3,76 posto), a njemačkim kao menaterinskim jezikom pak 5,52 posto žitelja Hrvatske. Na tragu novih podataka neki su mađarski zastupnici u Ugarskom saboru zamjerali Hrvatima protumađarsko stajalište, jer se nisu bunili zbog učenja njemačkoga, ali im je usvajanje mađarskoga jezika neprihvatljivo. Premda je za banovanja grofa Khuena- Héderváryja usvojen zakon o „preustroju pučke škole“ iz 1888. godine temeljem kojega je ban izdavao dozvole za osnivanje mađarskih škola (uglavnom za pripadnike mađarske nacionalne manjine u Slavoniji i tzv. željzničke škole), te je 1894. mađarski uveden kao obvezan nastavni predmet i u neke hrvatsko-slavonske gimnazije, ipak se teško može govoriti o jezičnoj asimilaciji Hrvata. Pod mađarizacijom se nije smatrao pokušaj asimilacije, nego bi se prije moglo reći da je bila riječ o nametanju političke prevlasti Ugarske nad Hrvatskom. Često se to događalo preko simbola kako bi se prikazala jedinstvenost zemalja ugarske krune što je hrvatska javnost teško prihvaćala. Prosvjedovalo se zbog mađarskih zastava na javnim zgradama u Hrvatskoj i Slavoniji istaknutih prigodom praznika (Hrvatsko-

15 Djela dra Ante Starčevića, izdaje Odbor Kluba Stranke prave, knj. III, Znanstveno-političke rasprave, Zagreb, 1894., pretisak, 1995, str. 315. Priopćava: Željko Holjevac, op. cit. http:// www.azoo.hr/images/izdanja/manjine/05.html (10. svibnja 2016.).

16 Cipek, Tihomir i Matković, Stjepan (prir.): Programatski dokumenti hrvatskih političkih stranaka i skupina 1842-1914., Zagreb, 2006., str. 121-125. Priopćava Holjevac, Željko, op. cit.

17 Holjevac, Željko, op. cit.

18 Šokčević, Dinko: Hrvati u očima Mađara, Mađari u očima Hrvata. Kako se u pogledu preko Drave mijenjala slika drugoga, Zagreb, 2006., 140-142. Priopćava: Holjevac, Željko, op. cit.

19 Obzor, 46/III, Zagreb, 25. 02. 1873. Priopćava: Holjevac, Željko, op. cit. 
ugarska nagodba propisala je da se u takvim prilikama, uz hrvatsku zastavu i grb trojednice, mogu isticati samo „sjedinjeni grbovi“ Ugarske i Hrvatske) ili natpisa na državnim uredima, željezničkim kolodvorima, razglednicama itd. Otpor takvim tendencijama kažnjavao se novčanim ili zatvorskim kaznama, odnosno raznim neugodnostima. ${ }^{20}$

Mađarske vlasti nisu posustale s takvom politikom ni početkom 20. stoljeća što je dovelo do snaženja nacionalnih pokreta nemađarskih naroda. Velika kriza nacionalnoga pitanja doživjela je vrhunac u vrijeme mađarskih koalicijskih vlada (umjesto Slobodarske stranke koja je samostalno vladala) od 1906. do 1912. Najveći udarac manjinama bio je Zakon o pravnim odnosima građanskih pučkih škola broj 1907: XXVII. usvojen 2. lipnja 1907. koji je po svom autoru, ministru bogoštovlja i prosvjete Albertu Apponyiju (1906.-1910.) nazvan Lex Apponyi. Propisao je da su tijekom četverogodišnjega školovanja svi učenici manjinskih škola dužni naučiti mađarski jezik te da pravo na državnu potporu imaju samo oni manjinski učitelji koji svojim učenicima pružaju „,besprijekoran domoljubni odgoj”. Mađari su protiv sebe okrenuli i Hrvate, kada su Zakonskim člankom o željezničkoj službi, broj 1907: XLIX. od 16. kolovoza 1907., propisali da je na željeznicama u cijeloj Ugarskoj u službenoj uporabi mađarski jezik, ali da je u Hrvatskoj potrebno i poznavanje hrvatskoga jezika. ${ }^{21}$ István Bibó je s tim u vezi primijetio kako su mađarski politički čelnici, radi unutarnjih političkih interesa donijeli 1907. dva zakona kojima su protiv Ugarske potpuno okrenuli sve manjine, a pošlo im je za rukom dati razlog Hrvatsko-srpskoj koaliciji da raskine veze s ugarskim partnerima. ${ }^{22}$ Ova je koalicija, naime, već ranije zacrtala put stvaranja južnoslavenske države, pa je po Bibóu željeznička pragmatika bila konačan povod Hrvatima za udaljavanje od Mađara.

U svjetlu ovih činjenica i zakonskih odredaba valja prosuđivati nacionalnu politiku grofa Khuen-Héderváryja. Premda je u Hrvatskoj dopustio djelovanje tzv. željezničarskih škola na mađarskom jeziku, treba kazati da te škole nisu bile javne, nego privatne. Činio je i druge ustupke ugarskoj vladi, jer ne treba smetnuti s uma da je bana imenovao i razrješavao kralj na prijedlog i uz supotpis ugarskoga ministra predsjednika, a za njegova banovanja se na toj dužnosti izmijenilo njih čak pet (Kálmán Tisza 1875,-1890., Gyula Szapáry 1890.-1892., Sándor Wekerle 1892.1895., Dezső Bánffy 1895.-1899., Kálmán Széll 1899.-1903.), prije nego je on sam sjeo u premijersku stolicu. Srbima u Hrvatskoj dao je vrlo široka prava i povlastice čime je naljutio mnoge Hrvate. No, jamačno je pridonio približavanju Hrvata i Srba, nakon što je između pripadnika dvaju naroda prethodno došlo do razmirica.

20 Isto.

21 U prijedlogu zakona koji je 13. svibnja 1907. u Ugarskom saboru predstavio ministar Ferenc Kossuth, stajalo je da zaposlenik na željeznici može biti samo onaj mađarski državljanin koji poznaje mađarski jezik. Na to su hrvatski zastupnici oštro prosvjedovali tvrdeći da se njime krši Hrvatsko-ugarska nagodba, pa je ugarska vlada u znak dobre volje prihvatila da u Hrvatskoj željezničari moraju razumjeti i govoriti i hrvatski jezik.

22 Bibó, István: Válogatott tanulmányok I-IV. I. kötet 1945-1949. Magvető Könyvkiadó. Budapest, 1986., str. 596. 


\section{KARLO GROF KHUEN-HÉDERVÁRY I HRVATSKO-SRPSKI ODNOSI}

Sabor je 1861. godine priznao srpski narod ravnopravnim hrvatskomu, ali je Hrvatska dvorska kancelarija pod vodstvom Ivana Mažuranića redovito izbjegavala nazive „hrvatski i srpski“ i za jezik i za narod, što nije bilo po volji zastupnika iz redova srpske narodnosti. ${ }^{23}$ Narednih godina su se Srbi nastojali izboriti za jednakopravnost i za priznavanje svoje nacije kao diplomatičkoga naroda. U tome je na saborskim sjednicama prednjačio Jovan Subotić, koji je u siječnju 1866. Saboru predložio da se u adresi kralju umjesto sintagme naš narod, koristi naziv hrvatsko-srbski narod, tvrdeći da takav naziv proizlazi iz zaključka usvojenoga 1861. godine. Hrvatski sabor je Srbima ispunio ovu želju početkom siječnja 1867. kada je za službeni jezik u Hrvatskoj i Slavoniji proglasio „hrvatski ili srpski”, a zatim je 11. svibnja 1867. svečano izjavio da trojedna kraljevina priznaje narod srpski koji u njoj stanuje kao s hrvatskim narodom istovjetan i ravnopravan. ${ }^{24}$

No to je trajalo kratko vrijeme, jer je Hrvatsko-ugarskom nagodbom uglavljeno da je hrvatski službeni jezik u Trojednici. No, uvođenje hrvatskoga jezika u službenu uporabu nije bilo po volji svih Hrvata. Svjedoči to i činjenica da su se tijekom pregovora kraljevinskih odbora u Pešti članovi hrvatskoga kraljevskog odbora međusobno razišli, pa su Mađari odlučili da će prihvatiti prijedlog većine. Josip Žuvić je na saborskom zasjedanju 24. rujna 1868. predstavljajući prijedlog većine u hrvatskom odboru, uz burno odobravanje, pljesak i povike „Živio!” kazao da se razlike između deputacija očituju i u tomu ... što manjina u našem zemaljskom izaslanstvu želi da se za zemaljski jezik u našoj domovini uvede srpsko-hrvatski. Poštovana gospodo zastupnicii! Ja priznajem u našoj domovini hrvatski narod i hrvatski jezik, priznajem i srpski narod u domovini i izvan nje, kao i srpski jezik koji se od hrvatskoga jezika razlikuje samo u nazivu, ali ne i u suštini. No, iskreno govoreći, srpsko-hrvatski jezik ne poznajem, a da takav postoji saznao sam iz prijedloga manjine. Sumnjam, međutim, da bi stvaranje ovakvog jezika s odobravanjem prihvatio istančani nacionalni osjećaj Hrvata i Srba. ${ }^{25}$

Odredbu Hrvatsko-ugarske nagodbe da je u Hrvatskoj u službenoj uporabi hrvatskijezik i latinično pismo Vasilije Krestić, akademik SANU smatra „ugrožavanjem Srba”. Kaže da su oni zbog toga morali povesti žestoku borbu za očuvanje srpskoga nacionalnoga identiteta, jer je bila zabranjena uporaba ćirilice u službenim dopisima državnih ustanova. ${ }^{26}$ Ona nije odobrena ni za banovanja Ivana Mažuranića. ${ }^{27}$

23 Polić, Martin: Parlamentarna povijest Kraljevine Hrvatske, Slavonije i Dalmacije. Dio prvi, od godine 1860. do godine 1867., Zagreb, 1899., str. 156, 157.

24 Kušlan, D. - Šuhaj, M.: Spisi saborski sabora kraljevinah Dalmacije, Hrvatske i Slavonije od godine 1865-1867, Zagreb, 1962., knj. I., str. 159.

25 Pesti Napló. 1868. br. 236-5540. srijeda, 14. listopada 1868.

26 Krestić, Vasilije: O nazivu jezika u prošlosti Hrvatske. Primljeno na II skupu Odelenja istorijskih nauka od 21. marta 1990., http://kovceg.tripod.com/vk_o_nazivu_jezika.htm (10. svibnja 2015.).

27 Čepulo, Dalibor: Ivan Mažuranić: liberalne reforme Hrvatskog sabora 1873.-1880. i srpska elita u Hrvatskoj. Dijalog povjesničara-istoričara: Herceg Novi, 1.-4. ožujka 2001. Ured.: Hans-Georg Fleck - Igor Graovac. Zaklada Friedrich Naumann. Zagreb, 2002., str. 278. 
Nezadovoljni hrvatski Srbi osnovali su Srpsku samostalnu stranku te su zatražili da im se i zakonom prizna ime srpsko (...), ravnopravnost ćirilskog pisma sa latinskom pismenicom $i$ da se u zemaljskom proračunu srazmierna svota opredieli na potrebu srbskih kulturnih potreba u ovoj zemlji, a za uočenje tih potreba, da se kod zemaljske vlade ustanovi miesto srpskog referenta... ${ }^{28}$ Te su svoje ciljeve ostvarili dočim je na bansku stolicu sjeo grof Karlo Khuen-Héderváry, pa je Sabor 1888. proglasio „hrvatski ili srpski" jezik za nastavni jezik u školama Trojedne kraljevine, a 19. listopada 1895. godine ban je izjavio da je srpska zastava u Hrvatskoj jednakopravna hrvatskoslavonsko-dalmatinskoj zastavi i da će je štititi tako dugo, dok je on ban.$^{29}$ Tako si je osigurao potporu srpske stranke, što mu hrvatska historiografija do danas predbacuje. József Bajza navodi da je Frano Supilo u svome uratku Politika u Hrvatskoj (Rijeka, 1911., str. 320.) izračunao da su za vrijeme banovanja grofa Khuen-Héderváryja u vladajućoj stranci bila 224 zastupnika Hrvata i 130 Srba, a u oporbi 104 Hrvata i dva Srbina. $^{30}$

Osim protežiranja Srba zamjera mu se i da je zajedno sa svojim vladajućim aparatom potiskivao i sve izraze i emanacije, koje bi, ma i indirektno, mogle služiti za razvijanje i buđenje hrvatske svijesti. U Slavoniji je Khuen bio pokrenuo, na ustuk hrvatstvu, kult, slavonstva'. Može se bez pretjerivanja reći, da je on hrvatstvo kao takovo, uz slavonstvo htio degradirati skroz na geografsku ekspresiju uže Hrvatske, bez Slavonije. Srpstvo je naprotiv sa strane samih predstavnika oblasti, počam od Khuena, bilo vrlo gojeno, štićeno... ${ }^{31}$

U svezi s narečenim valja primijetiti da su do nagodbe Hrvatska i Slavonija bile međusobno jasno razlikovane, a Miroslav Kraljević je čak (1863.-1865.) izdavao list nazvan Slavonac. Dakle, grof Khuen-Héderváry u poistovjećivanju sa slavonskim identitetom tada nipošto nije bio izuzetak, tim prije što su Mađari do nagodbe pod Slavonijom podrazumijevali samo Zagrebačku, Varaždinsku i Križevačku županiju, dok su Požeška, Virovitička i Srijemska županija držane sastavnim dijelom Ugarske (gdjekad su nazivane Donjom Slavonijom). Spomenimo i da je prema nagodbi Trojedna kraljevina službeno nazvana Hrvatska, Slavonija i Dalmacija, dakle slavonsko ime je i tada živjelo.

Najveći banovi oponenti bili su pristaše Stranke prava koji su ga optuživali zbog mađarizacije i sklonosti Srbima, ali su oni i svoje druge političke suparnike obilježavali raznim nazivima, poglavito "obzoraše" (Šimu Mazzuru i Marijana Derenčina prije svih) koje su nazivali "slavenosrbima". No, svakako je zanimljivo da je unatoč nesklonosti Srbima, pravašima slavenska ideja bila prihvatljiva, pa su tako bili oduševljeni Rusijom, koristili su se i julijanskim kalendarom i ćirilicom. ${ }^{32}$ No, postupno je oduševljenje splasnulo kada su uvidjeli da Rusi malo znaju o

28 Zastava, Novi Sad, 1883., br. 27.

29 Balta, Ivan: Pravnopovijesni hrvatsko-mađarski odnosi od dualizma do propasti monarhije, s posebnim osvrtom po pitanjima obrazovanja. U: Zbornik radova Pravnog fakulteta u Splitu. God. 43, br. 3-4. (83) str. 361-375., str. 363.

30 Bajza, József, op. cit., str. 224., 84. bilješka.

31 Artuković, Mato: Srbi u Hrvatskoj (Khuenovo doba). Bibliotheca Croatica: Slavonica, Sirmiensia et Baranyensia; knj. 2., Slavonski Brod., 2001., str. 8-9.

32 Iveljić, Iskra: Od uza Sudbenog stola do turneje po Rusiji, Nepoznata pisma Josipa Henneberga 
Hrvatskoj i Hrvatima uopće, a napose o njihovim težnjama za slobodom te da ni ne pomišljaju na nekakovu pomoć slavenskoj braći u Austro-Ugarskoj. ${ }^{33}$ Premda su se političke prilike u zemlji mijenjale, ipak je grof Khuen-Héderváry ostao najvećom prijetnjom svih pravaša, pa ga stoga često nazivaju pogrdnim imenima. Jedan od sudionika spaljivanja mađarske zastave 1895. pravaš Josip Hennenberg u pismu bratu Stanku od 26. ožujka 1895. piše: Moraš najme znati, da naš 'rodjo' 'državni' (Khuen-Héderváry op. autora) imade osobiti 'pik' na svaku i najmanju stvarcu, koja se tiče nagodbe. Mogao si opazit u predzadnjem broju kako smo morali na slici (Hej drváru! - aluzija na banovo prezime, op. autora) na'kobili' brisati zadnja slova, te je tako ostalo samo: 'nagod.' što je dakako nezaplienjivo. ${ }^{34}$ Osim toga se moramo čuvati $i$ arkivskih spisa s kojima se je takodjer vrlo škakljivo baviti. ${ }^{35}$ Spomenuti srednjovjekovni i novovjekovni arhivski spisi bili su tzv. komorski spisi (13 sanduka), koje je u vrijeme Jelačićeva pohoda na Budimpeštu 1849. Ivan Kukuljević (na banov poziv) s još nekoliko hrvatskih stručnjaka odijelio od mađarskih dokumenata te ih je iz Budimpešte donio u Zagreb. Iste je ban Khuen-Héderváry bez znanja Hrvatskoga sabora vratio u Budimpeštu tvrdeći da se nije radilo o zakonitu posjedu. To je bilo razlogom za izgred koji se 5. listopada 1885. navodno dogodio tijekom rasprave u Saboru (sudionici su na sudskom procesu tvrdili da nije bilo napada na bana), a o kojemu i danas hrvatska historiografija, ali i udžbenici pišu kao o hvale vrijednome događaju, baš kao i o spaljivanju mađarske zastave 1895. godine. ${ }^{36}$

$\mathrm{Na}$ ovome se mjestu ne želimo opširnije baviti ovima, u najmanju ruku dvojbenim pitanjima koja zahtijevaju široku elaboraciju, nego samo primjećujemo da je ban Jelačić s 35 tisuća vojnika „branio hrvatsku granicu” od „mađarskih presizanja” na teritoriju Mađarske i to zauzimanjem prijestolnice Budimpešte, pa je doista upitno jesu li tada odneseni hrvatski dokumenti pribavljeni na zakoniti način. ${ }^{37}$ Glede spaljivanja zastave prije bismo rekli da je to jedan necivilizacijski čin, a ne izraz domoljublja. U onodobnome tisku se nagađalo o stvarnim organizatorima studentskih

iz 1894.-1897. U: Časopis za suvremenu povijest, Vol. 40., No. 2. str. 309.-700., Zagreb, 2008., str. 587-624., ovdje str. 603.

33 Jedan od slavenofilskih banovih protivnika bio je i pravaš Krunoslav Jurjević Heruc koji je 1885. emigrirao u Bugarsku, gdje je bio član tajnog komiteta za sjedinjenje s Rumelijom i dragovoljac u bugarsko-srpskom ratu. No, 1886. morao je emigrirati u Rusiju, gdje je djelovao kao publicist, prevoditelj i knjižar te suradnik hrvatskih novina Slobodi, Hrvatskoj i Hrvatskom pravu. Vidi Iveljić, Iskra, op. cit., str. 601.

$34 \mathrm{U}$ pismu bratu od 8. travnja 1896. Hennenberg bana naziva bolesnikom: Ja sam se od Vence preselio u Gundulićevu ul. br. 25 prvi kat i to - gledaj sudbine! - gdji udovi pokojnog saborskog predsjednika Mirka Horvata. A lani kod Vukotinovićke! Budem li tako dalje avanzirao - a umre li g. bolestnik - to bi mogao do godine stanovati kod gdje udove ...nice! (Iveljić, Iskra, op. cit., str. 613.).

35 Iveljić, Iskra, op. cit., str. 599.

36 Grof Khuen Héderváry tijekom saborske rasprave kazao je da „dvoji o poštenom posjedu Hrvatske na te spise“, nakon čega su ga dok je odlazio u bansku sobu navodno pravaški zastupnici opkolili, te ga jedan uhvatio za vrat, a drugi udario. Kasnije su u sudskom procesu to opovrgli, ali je sud Grgi Tuškanu i Davidu Starčeviću oduzeo titulu iuris doctor te ih je osudio na šest mjeseci zatvora.

37 Ban je sa svojom vojskom 11. rujna 1848. prešao preko Drave te je ratovao u Mađarskoj „braneći Hrvatsku“. Njegova vojska bila je dvostruko brojnija od mađarskoga domobranstva. 
prosvjeda i spaljivanja zastave, ali je neprijeporno kako su sudionici bili uvjereni da su počinili domoljubni čin. ${ }^{38} \mathrm{O}$ tomu svjedoče i pisma pravaša Josipa Hennenberga $\mathrm{u}$ kojima se kaže: ... da ćemo rado tu kaznu trpiti, držeći ju samo službenom potvorom, da smo učinili pošten i patriotičan čin... Nisam zatvoren radi sramotna čina, nego se ponosim djelom koga počinih s mojim drugovima, u vrućoj ljubavi napram dragoj nam Hrvatskoj. ${ }^{39}$ Studenti su - jamačno i na temelju napisa u njima sklonim tiskovinama - bili uvjereni kako uživaju potporu širokih slojeva hrvatskoga naroda, pa Hennenberg piše: Priziva ne uložismo, jer bi značio, da se priznajemo krivima i da molimo milosti, a žaoba ništovna bi se mogla produljiti - dok bi bila riešena - možda dulje, nego što će nam sam zatvor trajati. Mi dakle nastupamo svi kazne i to danas 118. o. mj./, nu po savjetu odvjetnikâ uložit će naši roditelji, odnosno rodjaci i skrbnici žaobe ništovne. Za mene će dakle to morati učiniti tata, a pobliže o toj stvari javit će Vam ili Vence ili ja sam. U zatvoru nam je sada mnogo bolje nego prije, gotovo nit ne osjećamo, da smo zatvoreni. Nadamo se, da ćemo moći i nadalje dobivati koštu iz vana a molit ćemo sada i za slobodno primanje novina. Što se tiče naše budućnosti i ta je prilično osigurana, jer se je ovdje složio odbor, koji je osigurao za sedamdesetoricu naših - godišnjih 300 for. dok se ne izškolaju. Ja ću još razgovarati sa Vencom što bi bilo najbolje, da iza pretrpljene kazne radim. Neki naši idu u Moskvu, neki u Beč, Grac, Prag itd. Ja za sad pomišljam ponajviše na Prag. ${ }^{40}$ Nakon početne euforije postupno je i sam Hennenberg postao svjestan stvarne situacije što svjedoči i pismo od 8. veljače 1896. kada mu je postalo jasno da nisu točni glasovi koji su stizali do njih o silnoj svoti novca skupljenog za njihovo daljnje studiranje, pa da se on mora osloniti na vlastite snage i potporu obitelji. ${ }^{41} \mathrm{O}$ tomu kako je tisak (Obzor) uljepšao cijelu aferu svjedoči i činjenica da su dr. Ilija M. Prica i dr. Franjo Salavari sastavili sudski zapisnik glavne rasprave, koji se razlikuje od optuženicima nakolonjenijih „obzorovih" stenografskih izvješća. ${ }^{42}$

Zanimljivo je da su mnogi Hrvati banu Khuen-Hedervaryju zamjerali suradnju sa Srbima, premda je jugoslavenska ideja živjela i prije njega, ali i poslije. Naime, odmah poslije njegova odlaska iz Zagreba došlo do hrvatsko-srpskoga približavanja,

38 Sudski proces održan je (od 11. do 16. studenoga 1895.) na Sudbenom stolu u Zagrebu, pod predsjedanjem Aleksandra pl. Rakodczaya. Studenti su optuženi da su 16. listopada između 11 i 12 sati uz povik "Abzug Magjari” spalili ugarsku trobojnicu, a namjera im je bila zavesti stanovnike državne, jedne proti drugim, stoga je njihov čin kvalificiran kao prijestup protiv javnog mira i reda po čl. 302.Kaznenog zakona. (Vidi: Hrvatski djaci pred sudom. Stenografski izvještaj o glavnoj razpravi proti hrvatskim sveučilištnim djacima obdržanoj pred kr. sudbenim stolom u Zagrebu dne 11-16. studenoga 1895. (Preštampano iz Obzora), Zagreb, 1895., pretisak Zagreb 1995. Priopćava: Iveljić, Iskra, 2008., str. 591-592.). Ivan Frank usto je optužen i da je poticao svjetinu da nasrne na redarstvenika tijekom prosvjeda pred srpskom pravoslavnom crkvenom općinom i crkvom, a njegov brat Vladimir i za skidanje mađarske zastave sa slavoluka ispred Glavnog kolodvora. Osuđeni su na zatvorske kazne, a usto su izbačeni sa sveučilišta.

39 Iveljić, Iskra, op. cit.

40 Iveljić, Iskra, op. cit., str. 600.

41 Isto, str. 591.

42 Sudski zapisnik se nalazi u Hrvatskom državnom arhivu, fond Sudbeni stol u Zagrebu, $\mathrm{Kz}$ 14581/1091-95 iz 1895. g., V. B. Janjatović 2003. Stjepan Radić. Progoni-zatvori-suđenjaubojstvo (1889.-1928.), Zagreb, 2003., str. 46. Priopćava Iveljić, Iskra, op. cit., str. 600. 
sklapanja Riječke (3. listopada 1905.) i Zadarske (17. listopada 1905.) rezolucije, te do stvaranja Hrvatsko-srpske koalicije, koja je već 11. prosinca 1905. objavila svoj politički program. No, dok se Khuen-Héderváry zauzimao za očuvanje hrvatskougarske državne zajednice, jugoslavenstvo biskupa Strossmayera trsilo se povezati južnoslavenske narode oko Hrvatske, a srpski su političari u Hrvatsko-srpskoj koaliciji nastojali oživotvoriti ujedinjenje sa Srbijom. Grofu Khuen-Héderváryju predbacivalo se iskorištavanje i potenciranje srpsko-hrvatskih proturječnosti, kao i da je ljude koristio za ostvarivanje svojih ciljeva, ali su slično postupali i Srbi. Naime, poslije odlaska iz Hrvatske ,srpski ban” više nije uživao njihovu potporu, jer su tada svoje ciljeve mogli provesti uz pomoć Hrvata. ${ }^{43}$ Tako je odmah nakon njegova nastupnoga premijerskoga govora 27. siječnja 1910. Jovan Manojlović najavio da su zastupnici iz njegove Srpske radikalne stranke protiv Khuen-Hedervaryjeve vlade te će poduprijeti prijedlog za glasovanje o povjerenju vladi koje je podnio Gyula Juszt. ${ }^{44}$ Károly Khuen Héderváry tada je pokušao obnoviti unionističku stranku ustoličenjem bana Nikole Tomašića, ali se to pokazalo kao promašaj. Ni imenovanje kraljevskoga povjerenika Slavka (Ede) Cuvaja nije polučilo uspjeh, pa je tadašnji ugarski ministar predsjednik ostao bez potpore u „svojoj” Hrvatskoj, a Hrvatsko-srpska koalicija nastavila je svoju politiku južnoslavenskoga ujedinjenja.

\section{GROF KHUEN-HÉDERVÁRY KAO ZASTUPNIK HRVATSKIH INTERESA}

Karlo Khuen-Héderváry bansku je dužnost preuzeo u vrijeme žestokih nemira zbog tzv. Dávidovih ploča, a sličan val nezadovoljstva prethodio je i njegovu napuštanju ove funkcije. U ožujku 1903. široke narodne mase ustale su protiv njegove vlasti i mađarizacije, ali se u pozadini ovoga "narodnoga pokreta” nalazila i želja za rušenjem temelja dvojne Monarhije. Neposredni povod narodnom pokretu bila je uvreda nanesena Hrvatima od strane ugarske kraljevske deputacije u svezi obnove financijalne nagodbe između banske Hrvatske i Ugarske. Naime, Mađari su ustvrdili da je Hrvatska prosjačka zemlja i da Ugarska uzdržava Hrvatsku ${ }^{45}$ Prosvjedi, nemiri i ulični sukobi diljem Hrvatske tijekom ožujka 1903. izbili su nakon pojavljivanja mađarskih natpisa na novoj zgradi željezničke prometne uprave i na javnim zgradama državnih ureda, čime je prekršena Hrvatsko-ugarska nagodba. U Zagrebu su

43 O tome svjedoči i diskusija Mihajla Polita Desančića 20. siječnja 1909. povodom interpelacije premijeru Sándoru Wekerleu u svezi sa sudskim sporovima koji su se zbog veleizdaje vodili protiv Srba. Tada je kazao: Je li raniji ban Khuen-Héderváry poricao srpstvo u Hrvatskoj? Nije, nego si je znao stvoriti jednu srpsku stranku, dapače, nije ga smetalo ni to ako su ga nazivali 'srpskim' banom. U: Dnevnik Zastupničkog doma (Képviselőházi Naplo), 1906., XXIII., str. 61-64. Vidi: Kemény, G. Gábor: Iratok a nemzetiségi kérdés történetéhez Magyarországon a dualizmus korában. V. (1906-1913). Tankönyvkiadó, Budapest, 1971., str. 266-267.

44 Dnevnik Zastupničkog doma (Képviselőházi Napló) 1906., XXVI., str. 160-162. I Kemény, G. Gábor: Iratok a nemzetiségi kérdés történetéhez Magyarországon a dualizmus korában. V. (1906-1913), str. 320., fusnota br. 1.

45 Dobrovšak, Ljiljana: Židovi u banskoj Hrvatskoj u zbivanjima 1903.-1904. U: Časopis za suvremenu povijest Zagreb, 2005., br. 3., str. 635-652., str. 636. 
prosvjednici razbili prozore na zgradi prometne uprave, demolirali su zgradu Narodnih novina te poskidali ili porazbijali sve natpise na stranim jezicima (njemačkom i mađarskom). Budući da su neredima prethodile javne skupštine, njihovo je održavanje zabranjeno. Vrhunac nezadovoljstva narodnih masa uslijedio je 11. travnja 1903., kada je na željezničkom kolodvoru u Zaprešiću izvješena mađarska zastava, što su Hrvati ocijenili provokacijom, te su ju skinuli. Došlo je do sukoba, pa je uredovalo oružništvo. Potekla je krv, zbog čega su izbili novi prosvjedi i protumađarske akcije ne samo u Hrvatskoj i Slavoniji, nego i u Dalmaciji. Prosvjednici su razbijali prozore pristaša mađarske politike, izbacivali su mađarske činovnike iz ureda, zapalili su mađarske zastave i banove fotografije, te su napadali posjede mađarona. Stradali su i mnogi Židovi, s obzirom da su u javnom i privatnom životu govorili mađarski, pa su ih stoga držali Mađarima ili mađaronima. ${ }^{46}$

Ban je žestoko uzvratio šaljući oružništvo da se obračuna s pobunjenim pučanstvom. Zatvori su bili prepuni, mnoge su prosvjednike premlatili. No, na dvoru i u Pešti hrvatska politika grofa „Dragutina” Khuena-Héderváryja ocijenjena je neuspješnom, jer je protiv Ugarske, ali i Beča okrenuo većinu hrvatskoga naroda. Stoga je 27. lipnja 1903. razriješen, ali je bansku stolicu voljom svoga mentora Franje Josipa I. zamijenio višom funkcijom ugarskoga ministra predsjednika, a na njegovo je mjesto imenovan grof Teodor Pejačević. ${ }^{47}$

Premda stoje zamjerke da je preferirao srpski narod na štetu Hrvata, da je potiskivao hrvatske nacionalne težnje, da je favorizirao regionalizam (bio je Slavonac), te da je prije dolaska u Zagreb u ugarskom tisku objavljena izjava kako mu je ,rodište tamo, a domovina ovdje, a oboje je zajednička domovina", valja ipak napomenuti da je u svome nastupnome banskom govoru kazao: Primite molim vas izjavu i budite uvjereni da izim neuzkolebive vjernosti prama milostivomu kralju i vladaru, prama državi, zakonu i narodu, označivati će sve moje djelovanje ona ljubav, koju osjećam naprama zemlji, koja me je u djetinjstvu gojila, te mi tim ostala domovinom najmilijih i najsvetijih uspomena, ona ljubav koja se je razvila pod čarom poetičnoga mišljenja i shvaćanja našega naroda. ${ }^{48}$

Osim ovih čuvstava prema Hrvatskoj, ban je i među najbližim suradnicima imao vrlo istaknute hrvatske intelektualce. Uz Izidora Kršnjavija to je nadasve bio još jedan Slavonac, profesor zagrebačkoga sveučilišta Josip Pliverić (Nova Gradiška 1847. Zagreb, 1907.), jedan od najnapadanijih Hrvata u ugarskom saboru (uz Antu Starčevića i biskupa Strossmayera). Pliverić je, naime, bio najsnažniji zagovornih hrvatskoga državnog prava i jedan od najboljih poznavatelja Hrvatsko-ugarske nagodbe, koji je ostao upamćen po javnoj polemici s bečkim i heidelberškim profesorom Georgom Jellinekom, najvećim pravnim autoritetom u Austro-ugarskoj monarhiji. Prof. Jellinek je na koncu polemike donekle revidirao svoja stajališta o hrvatsko-ugarskoj državnoj zajednici, što je bio velik Pliverićev uspjeh, kojemu se u Ugarskoj nimalo nisu radovali. ${ }^{49}$ Mađari su redovito napadali bana zbog Pliverića koji je odgojio

46 Horvat, Josip: Politička povijest Hrvatske I. Zagreb, 1989., str. 251-252.

47 Perić, Ivo: Hrvatski državni sabor 1848.-2000. (drugi svezak 1868.-1918.), Zagreb, 2000., str. 342.

48 Polić, Martin, op. cit., str. 14.

49 Profesor Pliverić jedan je od utemeljitelja ustavnog prava u Hrvatskoj, profesor državnog i 
naraštaje zagrebačkih pravnika u duhu hrvatske državnosti kao pravne kategorije, a usto je sustavno pobijao teze mađarskih državnopravnih teoretičara i parlamentarnih zastupnika o jedinstvenoj ugarskoj državi. Ne stoji dakle tvrdnja da je grof Khuen Hédervary zatirao svaki vid hrvatske nacionalne ideje, jer je Pliverić kao osoba od njegova povjerenja bio članom izaslanstva Hrvatskog sabora u budimpeštanskom državnom saboru, a imenovan je i rektorom Zagrebačkog sveučilišta od 1892. do 1893. godine. O banovoj nacionalnoj pripadnosti mogli bismo reći da je bio i Mađar i Hrvat i Austrijanac, ali i kozmopolit. Naime, čini se da njemu nacionalna pripadnost nije značila razdvajanje, nego zajednicu. To tvrdi i Đuro Đurković pišući: Ostavimo po strani krvna zrnca i ne odijevajmo na njega attilu (mađarsku odjeću -op. autora), nego frak, jer je Khuen europski čovjek, pravi gentleman... ${ }^{50}$ Svakako valja istaknuti da je grof Khuen-Héderváry besprijekorno govorio hrvatski, pa je kao premijer gdjekad ispravljao zastupnike jer nisu najbolje razumjeli poneki tekst iz hrvatskih novina, nadalje da je u krugu svojih bliskih prijatelja imao mnoge Hrvate, kao i da je njegova supruga - rođena Mađarica - grofica Margit Teleki naučila hrvatski jezik, te je u Zagrebu sudjelovala u brojnim dobrotvornim pokretima preuzimajući vodeću ulogu. Glavni grad Hrvatske ima zahvaliti grofici Khuen-Héderváry što je uz ženski licej ustrojena još jedna izvanredna ustanova za obrazovanje djevojaka u kojoj se besplatno školuju djevojke bez roditelja iz sredstava fonda koja je bivša banica prikupila donacijama svojim neumornim jednogodišnjim radom. Tim ženskim internatom upravlja ,društvo zagrebačkih dama" u čijem krilu je grofica Khuen-Héderváry radila kao osnivačica $i$ predsjednica... Važnu djelatnost je ostvarila i kao predsjednica zagrebačkoga odjela mađarskoga Crvenog križa.$^{51}$

Zagreb može narečenome banu zahvaliti puno toga, među inim i veličanstvenu Jubilarnu izložbu na blagdan Velike Gospe 1891. godine. Po pisanju Narodnih novina predsjednik „Egzekutivnog odbora” Ljudevit Vukotinović tom je prigodom kazao: ... naša izložba uređena je u čednih granicah gospodarskog djelokruga jedino u tu svrhu, da narod vidi svoju snagu, da upozna sam sebe, da na temelju tog spoznjanja upre svu snagu svoju kako da dođe sve bliže krugu kulturnih zemalja... Potom je zamolio bana da „udostoji” otvoriti izložbu što je on učinio uznositim i s najvećom pažnjom saslušanim te često usklicima isprekidanim govorom koji je završio ovim riječima: ,Moleć se svemogućem Bogu koji svojom milošću i dobrotom prati naš narod, neka uzme i ovaj podhvat milostivo u svoju zaštitu. Ovim časom proglašujem Jubilarnu izložbu gospodarskoga družtva otvorenom'. ${ }^{52}$

I na kraju istaknimo kako se ban gdjekad znao zauzeti za hrvatske pravice čak i po cijenu sukoba s ugarskom vladom. Do prvoga je razmimoilaženja s Peštom došlo 1895. godine kada je zahladnio odnos između hrvatskoga bana i ugarskoga

međunarodnog prava, te rektor u dva navrata (1892.-1893. i 1904.-1905.), a usto je bio zastupnik Hrvatskoga sabora od 1893. do 1906. te član hrvatskoga zastupstva u Ugarskom parlamentu od 1897. do 1905.

50 Gyurkovics, György 1903. Grőf Khuen-Héderváry mint államférfi, és mint ember. U: Vasarnapi Újság 1903., br. 30., str. 420.

51 Gróf Khuen-Héderváry családja. In: Vasárnapi Újság 1903., 50. god., br. 27., str. 434-435.

52 Narodne novine, LVII. br. 186. Zagreb, 15. VIII 1891. Priopćava: Gostl, Igor: Najveća predstava u Zagrebu. ABC, Zagreb, 1966., str. 57. 
premijera Bánffyja (za kraljeva posjeta ban je sjedio lijevo do kralja, a ne ugarski premijer) i njihovih vlada. Naime, grof Bánffy je odmah nakon zagrebačkoga izgreda u parlamentu primio hrvatsko izaslanstvo koje mu je predalo povelju o primanju u red počasnih građana hrvatske prijestolnice. Vlada premijera Bánffyja uoči novoga sazivanja Sabora vodila je povjerljive razgovore s čelnicima Stranke prava i s unionističkim oporbenjacima o možebitnome smjenjivanju grofa KhuenHedervaryja, te o stvaranju vlade sastavljene od starih unionista koji su ojačali nakon što je hrvatski ban u svoju vladu pozvao Josipa Pliverića. Narečeni profesor bio je neprihvatljiv starounionistima, pa su istupili iz Khuenove stranke i postali alternativa hrvatskome banu. Na čelu ovih nezadovoljnika stajali su Nikola Crnković, Gejza Jelačić, Gejza i Pavao Rauch koji su uživali naklonost mađarske vlade. Već u jesen 1896. su se pravaši i starounionisti otvoreno sukobili s hrvatskim banom. Nezadovoljnici u redovima unionista su 21. listopada 1896. u svojoj spomenici pod nazivom Characteristik der Regierungstätigkeildes Banus grafen Karl KhuenHéderváry... ${ }^{53}$ napisali da ban ignorira prave unioniste, da nije dovoljno odlučno postupio prema oskvrniteljima mađarske zastave (1895.) te da hrvatske poslove vodi „sa svojim Srbima.” Kriza u Hrvatskoj se razbuktala u rujnu 1897. kada su Khuenov nuštarski dvorac napali slavonski seljaci iz okolice, u Slavoniji i Banskoj krajini prosjedovalo se zbog mađarskih zastava, a nakon što su prosvjednici na smrt pretukli tri činovnika, uvedeno je izvanredno stanje. U listopadu 1897. su predstavnici desne oporbe (Crnković, Rauchovi i Folnegović) stupili u neposrednu vezu s odjelnim predstojnikom Ministarskoga vijeća Dárdayem, ali pokušaj banova smjenjivanja nije uspio zahvaljujući kralju. Narečeni događaji su po Gáboru G. Keményu motivirali hrvatskoga bana da se počne odlučnije boriti za ovlasti svoje autonomne vlade u odnosu prema Ugarskoj. U toj se nakani odupro nacrtu vladina odgovora na dogovor mađarskoga i austrijskoga ministra pravosuđa o izvršenju sudskih presuda. Naime, ugarski je ministar Sándor Erdély svome austrijskome kolegi kazao kako je Hrvatska kao posestrima zemlja Ugarske nerazdvojni dio državne zajednice i time sastavni dio ugarske Svete krune. Zbog toga ona nema međunarodni subjektivitet, pa hrvatska vlada nema ovlasti pregovarati s Bečom. Stoga je zamolio austrijskoga kolegu da pregovore započete s Hrvatskom obustavi te da s Ugarskom pregovara i u vezi s Hrvatskom. No, ban se tomu usprotivio, pa je u prijepisu broj 8062 od 18. lipnja 1897. izjavio da iz neraskidive državne zajednice između Hrvatske i ostalih zemalja Krune Svetoga Stjepana ne proizlazi zaključak koji je iz toga izvela ugarska vlada te da on ne može prihvatiti stajalište da hrvatska vlada u narečenome pitanju ne može samostalno urediti odnose s austrijskom vladom. ${ }^{54}$ Pozvao se na nagodbene članke 3. i 4. iz kojih proizlazi da u autonomnim poslovima Hrvatsku prema inozemstvu zastupa carsko i kraljevstvo ministarstvo, a unutar monarhije - dakle prema Beču i Budimpešti Trojednu kraljevinu zastupa njezina vlada, odnosno ban. Ban je priznao da je ugarska vlada ovlasna postupati u ime Hrvatske glede trgovinskih i državnih ugovora tičućih

53 Predsjednik Vlade(ME) 1898 - XVII - 1.686. Priopćava: Kemény, G. Gábor: Iratok a nemzetiségi kérdés történetéhez Magyarországon a dualizmus korában, III. 1900-1903., Budapest, 1964., str. 614.

54 Kemény, G. Gábor: Iratok a nemzetiségi kérdés történetéhez Magyarországon a dualizmus korában, III., 1900.-1903., str. 613. 
se svih zemalja Krune Svetoga Stjepana. Radi potvrde svojih stajališta naveo je da je sukladno članku 9. u svezi s člankom 47. nagodbe potvrđivanje ugovora koji spadaju pod autonomne poslove u ovlasti bana i sabora, a samo potpisivanje ugovora je $\mathrm{u}$ ovlasti hrvatske vlade onda, ako je riječ o konvenciji s Mađarskom ili Austrijom. Istaknuo je da se u predmetnom slučaju radi tek o običnom konstatiranju uzajamnosti utemeljenom na autonomnim propisima, a to nitko drugi nije pozvan utvrditi do li najviše pravosudno tijelo Hrvatske i Slavonije, koje je potpuno neovisno o središnjoj ugarskoj vladi. Mađarska strana (ministarstvo pravosuđa) je ostala kod stajališta da se Hrvatska nalazi u neraskidivoj državnoj zajednici s Ugarskom, pa stoga nije zasebna država i nema međunarodni subjektivitet. Zastupala je mišljenje da Hrvatska ima pravo zakonotvorstva i izvršenja glede autonomnih poslova, ali ne i pravo zastupništva, jer suverenitet pripada samo mađarskoj državi što potvrđuje i članak 9. nagodbe. Zbog svega toga Ugarsku kao cjelinu u odnosu prema Austriji može zastupati samo ugarska vlada. Pešta je tvrdila da po banovu tumačenju ispada da Austro-Ugarsku Monarhiju ne čine dvije, nego tri države, a time postaje upitan i sam dualizam. Konačnu odluku u ovome sporu donijelo je Ministarsko vijeće koje je dakako, jednoglasno potvrdilo mađarsko stajalište po kome Hrvatsku može zastupati samo mađarska vlada. ${ }^{55}$

U obranu Hrvatske i Hrvata ban je stao i 1903. godine kada je u budimpeštanskom tisku sustavno napadana Hrvatska, a u biti sam ban, jer nije provodio mađarsku politiku, ili barem ne u onoj mjeri kako su to Mađari željeli. Protiv ,protuhrvatskih napisa” ban je 1903. pisao „poštovanome prijatelju” ministru predsjedniku Kálmánu Széllu. U pismu kaže da se čini da dnevni list Hazánk „inscenira hajku” na njega premda ga „dosad izrijekom nije imenovao”. Ovaj seljaštvu bliski list često je pisao o proganjanju Mađara u Slavoniji (A magyarság üldözése Szlavoniában, 5. srpnja 1901. I., br. 157.) i o slavonskome pitanju (A szlavon kérdés, 16. srpnja 1901. I., br. 166.). Broj Mađara je u prvome članku procijenjen na realnih sto tisuća, a u drugome već na tristo tisuća, te se u napisima kaže da ih hrvatske vlasti proganjaju i nezakonito gospodarski šikaniraju. Zbog toga su uz suradnju Zemaljskoga zajmenoga saveza (Országos Hitelszövetkezeti Központ) u trideset slavonskih naselja s mađarskim pučanstvom osnovane kreditne zadruge s mađarskim kapitalom i mađarskim jezikom kao službenim. Hrvatska javnost je glasnim negodovanjem primila osnivanje ovih zadruga, kao i djelovanje vjerskih i privatnih (željezničkih) škola na mađarskome jeziku. U mađarskoj historiografiji i ondašnjim parlamentarnim raspravama se protumađarsko raspoloženje smatra glavnim razlogom što su slavonski Mađari konvertirali na protestantizam, kao i za nastanak Julijanskog pokreta. ${ }^{56}$ Položaj hrvatskoga bana bio je vrlo nezahvalan, jer su s jedne strane Mađari zahtijevali ne samo da zaštiti, nego i da pomaže Mađare u Hrvatskoj, a s druge je strane kao hrvatski ban bio dužan štititi prava Hrvatske i autonomiju Trojedne kraljevine. Položaj mu je otežavala i činjenica da su hrvatske tiskovine svaki vid organiziranja Mađara u Slavoniji doživljavale kao pokušaj mađarizacije i izraz mađarskoga šovinizma,

55 Ministarsko vijeće (MT) 1897: XXXIV/11. Priopćava: Kemény, G. Gábor: Iratok a nemzetiségi kérdés történetéhez Magyarországon a dualizmus korában, III., 1900.-1903., str. 615-617.

56 Ministar predsjednik - ME 1903-XVII-1105. Priopćava Kemény, G. Gábor, op. cit., str. 156. 1. fusnota). 
iako su Mađari činili manje od četiri posto pučanstva. S druge su strane mađarske novine bile nezadovoljne banovim angažmanom na polju zaštite Mađara, pa su ga uz spomenuti Hazánk napadali i provladin Pesti Napló u članku Hrvati i Srbi (Horvátok és szerbek) u broju 179. od 2. srpnja 1901., kao i dualizmu neskloni Budapesti Hírlap koji su svojim protuhrvatskim napisima pridonijeli radikalizaciji hrvatsko-mađarskih odnosa. Želeći smiriti situaciju ban se u pismu s nadnevkom 17. srpnja 1901. požalio premijeru zato što se na žalost u mađarskome tisku sveudilj objavljuju članci koji blate svekoliki hrvatski narod, pa tako nedavno i u Pesti Naplóu. Nema niti jednoga napisa koji bi ga uzeo u zaštitu. To nije dobro, što sam ti već usmeno jednom i spomenuo. Odjek toga pisanja ne samo što neće poboljšati stvari, nego će ih dodatno pogoršati, jer će ozlovoljiti i naljutiti i one lojalne. ${ }^{57}$

Grof Khuen-Héderváry se o hrvatsko-mađarskome nacionalnom pitanju očitovao u svome nastupnome premijerskome govoru 30. lipnja 1903. i to u pomirljivome tonu. Tada je u Zastupničkome domu kazao kako u Ugarskoj postoje samo mađarski državljani, te da se mađarski jezik mora govoriti na cijelom njezinom teritoriju, ali se to smije ostvariti samo nenasilnim sredstvima i bez raspirivanja mržnje. Dodao je da su interesi mađarskoga naroda i drugih nacionalnosti identični. Glede Hrvatske je napomenuo da je odnose s njom uredio Zak. članak 1868:XXX. Radujemo se što je ona tim zakonom priznata političkim narodom pa nesmetano ostvaruje svoje kulturne ciljeve. Nadamo se da će poštivanjem državne zajednice najbolje služiti mađarskoj državi kao i svojim posebnim interesima. (Odobravanje na desnici i ljevici). Polazeći od toga vlada će nastojati što prije sklopiti financijalnu nagodbu ali vodeći računa o nužnoj štednji. ${ }^{58}$

Hrvatsko pitanje je obnovljeno dva tjedna kasnije tijekom rasprave o premijerovoj hrvatskoj politici i o mađarskim školama u Hrvatskoj. Zastupnik i publicist József Vészi je reagirajući na program ministra predsjednika u svezi s ovim pitanjima kazao da je svojih 20 godina provedenih u Hrvatskoj prikazao kao ideal prava, zakona $i$ pravednosti. ${ }^{59}$ Analizirao je kakovu Hrvatsku je kao ban zatekao (,uzavrelu austrijsku pokrajinu”), a kakovu je ostavio iza sebe (,unezvjerenu jugoslavensku državu”) te je zaključio kako je „rezultat premijerova dvadesetogodišnjega banovanja” nastanak ,jugoslavenske države”. Njegove su riječi izazvale žestoku reakciju i ispravak kolega da „Hrvatska nije država”, na što je govornik kazao da je svoju tvrdnju izrekao ironično. U nastavku izlaganja naveo je da je ministar predsjednik pogrešno shvatio svoj poziv jer je mislio da će u Hrvatskoj napraviti red, a njega je već napravio kraljev povjerenik Ramberg. „Njegovo poslanje je bilo da pomiri hrvatska nacionalna čuvstva

57 Predsjednik vlade - ME osn. br. 1903 - XVII - 1105. (1902 - XXII - 260 1600). Priopćava Kemény, G. Gábor, op. cit., str. 156.

58 Dnevnik Zastupničkoga doma (Képviselőházi Napló), 1901-1906, XVII. str. 198-203. Usp. A 1903 jún. 30 Gr. Khuen-Héderváry Károly miniszterelnök nyilatkozata a nemzetiségi kérdésben: az új kormány bemutatkozásakor. U: Kemény G. Gábor: Iratok a nemzetiségi kérdés történetéhez Magyarországon a dualizmus korában. IV. 1903-1906. A nemzetiségi kérdés képviselöházi vitája a hivatalba lépö gr. Khuen-Héderváry Károly miniszterelnök programnyilatkozatával kapcsolatban. U: Dnevnik Zastupničkog doma (Képviselőházi Napló, 1901.-1906., XVIII. Budapest, 1966. str. 291-293., 295-298.

Kemény G. Gábor, op. cit., str. 9-11. 
s idejom jedinstvene mađarske države... a umjesto toga je ostavio zatvor u kojemu su se robijaši pobunili, pa je upravitelj zatvora premješten."- kazao je Vészi. ${ }^{60}$ Osporio je banu da je to postupao u interesu Mađara. Njegov su govor prekidale upadice kako Mađari u Hrvatskoj nisu mogli dobiti ,ni mađarsku školu”, kako se u Zagrebu ne smije mađarski progovoriti niti u konačištima, a grofu Khuen-Héderváryju je zamjereno i što je „Tomašića doveo za ministra”. Vészijeve tvrdnje opovrgnuo je kolega mu po peru Stevan Vasin Popović (Popovics Vászin István) koji je kazao da u Srijemu postoji škola na mađarskom, nakon čega je zastupnik Vészi nastavio izlaganje kazujući kako uspjehe g. ministra predsjednika najbolje potvrđuje činjenica da je u samo šest mjeseci Hrvatska vidjela dvije revolucije, jednu su Hrvati vodili protiv Srba, a drugu protiv Mađara. Isprovocirati dvije revolucije tijekom šest mjeseci spada među svjetske rekorde.$^{61}$ Stevan Vasin Popović mu je odgovorio 14. srpnja 1903. napominjući da su zakonom o školama iz 1888. ustrojene javne škole ,na hrvatskom ili srpskom jeziku” te vjerske i privatne škole na materinskom jeziku polaznika škole u kojima se hrvatski (ili srpski) predaje kao obvezni predmet. Na stol je podastro najnoviji broj službenog lista od 30. lipnja 1903. iz kojega je vidljivo da je u netom završenoj školskoj godini u Hrvatskoj bilo 1400 pučkih škola, od kojih 1327 javnih, 40 vjerskih i 33 privatne škole. Među potonjima su djelovale 24 mađarske pučke škole. Opovrgnuo je i Vészjevu tvrdnju o premijerovu dvadesetogodišnjem neuspješnom banovanju nazivajući grofa Khuen-Héderváryja „izvanrednim državnikom” koji je uredio upravu, poboljšao pravosuđe, promet, javnu prosvjetu i pridonio kulturnom razvitku. Zauzeo se za to da se ne pokušavaju obnoviti nemiri u Hrvatskoj nakon što je konačno zavladao mir. ${ }^{62}$

O hrvatskom pitanju opet je bilo govora u prigodi rasprave o proračunu za 1904. godinu. U diskusijama u Zastupničkom domu projicirala su se tri različita gledišta o hrvatsko-ugarskim odnosima. Hrvatski zastupnik Stjepan Vuković iznio je stajalište svojih kolega koji su od 1868. redovito delegirani iz redova vladi sklonih saborskih zastupnika (tzv. mađarona). Nešto drukčije mišljenje imao je ministar za odnose s kraljem grof Károly Khuen-Héderváry, dok su treće gledište zastupali članovi Stranke neovisnosti Géza Polónyi i Béla Komjáthy. Međutim, niti jedno od ova tri gledišta nije zrcalilo stvarnu sliku stranačkoga i društvenoga stanja u Hrvatskoj. Osobito su u procjeni stanja u Trojednici griješili pristaše Stranke neovisnosti koji su se često obrušavali na hrvatske zastupnike držeći njihova stajališta pretjeranima, a ni ne sluteći da su ona tek ublažena projekcija pravoga raspoloženja u Hrvatskoj. Tek je pobjeda Hrvatsko-srpske koalicije otkrila koliko su se Hrvati udaljili od Mađara.

U raspravi je prvi prozborio Stjepan Vuković kazavši kako je u diskusiji o proračunu uobičajeno osvrnuti se na stanje u Hrvatskoj, pa bi on želio iznijeti svoje gledište o hrvatsko-mađarskim odnosima. Istaknuo je da oporba „u zadnje vrijeme” iznosi vrlo negativno mišljenje o tim odnosima, kao i o ljudima koji se u Hrvatskoj trse poboljšati ih. ${ }^{63} \mathrm{Na}$ zamjerku Ödöna Barte da ,„̌etrdeset Hrvata čini posebno

60 Isto.

61 Isto.

62 Dnevnik Zastupničkoga doma (Képviselőházi Napló) 1901.-1906., XVII., str. 295-298.

63 34. A horvát kérdés az 1904. évi költségvetés vitájában, A 1904 jún. 27. Kovácsevics István horvát-szlavon képviselö beszéde a horvát kérdésröl az 1904. évi költségvetési vitában. In: Kemény, G. Gábor: Iratok a nemzetiségi kérdés történetéhez Magyarországon a dualizmus 
zastupništvo u parlamentu" (njih je Sabor delegirao u Peštu), ali ih on nikad nije vidio da su zajedno istupili kada se govori o načinu poboljšanja gospodarskog stanja Ugarske ili o zaštiti ugarskih interesa od Austrije, zastupnik Kovačević odgovorio je da je on već ranije kazao da ćemo mi Hrvati zajedno sa Slobodarskom strankom uvijek zaštiti interese mađarske države (odobravanje na desnici),kao što smo to $i$ ranije činili (odobravanje na desnici). Kazao je da Hrvati nisu sudjelovali u opstrukciji (provodili su ju mađarski oporbenjaci), te nikada ničim nisu ometali rad parlamenta, kao i da će on osobno pridonijeti izgradnji mađarske države, zaštiti njezinih interesa te mađarizaciji vojske na način da zapovjedni jezik u njezinu mađarskom dijelu bude mađarski, a u hrvatskome dijelu hrvatski. Naveo je da se hrvatski zapovjedalo u boju kod Bihaća 1878. kada su dvije hrvatske pukovnije spasile cijelu vojsku od pogibelji, pa bi bilo sukladno i Austro-ugarskoj nagodbi da se unutar Ugarske kao zapovjedni jezici koriste mađarski i hrvatski.

U nastavku govora zauzeo se za očuvanje državnog jedinstva koje nije rezultat ugarskih osvajanja, nego slobodne volje hrvatskoga naroda. Pravu buru izazvala je izjava ovoga iskrenoga zagovornika mađarsko-hrvatskoga prijateljstva da je bespredmetna rasprava o Rijeci jer je ona i Hrvatska i Mađarska. Naime, država je jedna, pa je nebitno kojemu dijelu pripada. Prvi je protiv izjave prosvjedovao Gusztáv Beksics, a Lajos Olay je uzviknuo: Što sad kažete? Plješčite mu To je mađarsko stajalište. Ti Beksics. I ti Hodossy! Sad plješčite. Ovijte mu se o vrat! U sabornici je nastala velika buka koju je predsjednik doma pokušavao utišati zvonjavom. Miklós Pozsgay je negodujući kazao: Zato je šteta bilo dati tri milijuna!, a Lajos Olay je uz zvonjavu predsjedničkoga zvonca doviknuo: Sramota je tako zboriti u mađarskom parlamentu. Gore je nego kod narodnosti. Vi to slušajte, ali ja ne želim tako nešto čuti u mađarskom parlamentu! Na opetovano oglašavanje zvonca obratio se predsjedniku neka izvoli spriječiti ovakove izjave, što je ovaj odbio kazujući da nema ovlasti miješati se u to što će tko govoriti.

Stjepan Kovačević je nakon ovih nemilih scena nastavio izlaganje kazujući da se dvije zemlje nalaze u realnoj uniji, pa je mađarska država vlasna na hrvatskoj obali otvarati luke i u Bakru, Crikvenici, Novom Vinodolskom, Senju, isto kao i u Rijeci ${ }^{64}$ Spomenuo je i riječku krpicu, kao i da je do 1870 -ih hrvatska javnost bila sklona Ugarskoj, a poslije toga je na učinak crkvenih krugova i tiska atmosfera u društvu promijenjena. Osvrnuo se i na tvrdnju zastupnika Ödöna Barte da je nasilni postupak prema Srbima u Zagrebu nanio štetu Ugarskoj. Ti prekršaji nisu nikome naškodili, ali su nanijeli moralnu štetu hrvatskom narodu. Nije Mađarska država platila ni počinjenu materijalnu štetu kako to misli Ödön Barta, nego su to učinili građani Zagreba. Međutim, pogrešno je uvjerenje da su se protusrpski prosvjedi u Zagrebu dogodili zato što su Srbi prijatelji mađarske države, ili su joj privrženi, zato što su prihvatili mađarsku državu isto kao i Hrvati. Prije par godina su u jednom selu kod Karlovca Srbi cijeloga dana mučili i na kraju ubili na prostoru ispred crkve tri hrvatska službenika, od kojih jednoga etničkoga Srbina, samo zato što im je netko

korában. IV. str. 283. Usp. Dnevnik Zastupničkog doma (Képv. Napló), 1901.-1906., XXVI., str. 70-82. 
kazao da su htjeli izvjesiti mađarsku zastavu na crkvu... Na koncu je odbacio i tvrdnju da su Hrvati u povoljnijem financijskom položaju od Mađara, jer dok Mađarska za unutarnje poslove - bogoštovlje, prosvjetu i pravosuđe - troši samo 17 posto prihoda, dotle mi za to trošimo 44 posto naših prihoda... Neispravna je i tvrdnja da možemo biti sretni što je 1868. utvrđeno da se za iste poslove izdvaja 4400000 kruna, sada se za njih izdvaja više od 16 milijuna. ${ }^{65}$ Objasnio je da iznos od 4400000 kruna 1868. značio 60 posto hrvatskih prihoda. Od tada je u Hrvatsku uključeno jedanaest pukovnija Vojne krajine čime su značajno povećani rashodi. Kazao je i da je golema pogreška počinjena kada su Mađari smijenili hrvatskoga bana baruna Raucha zbog hajke na njega, jer je smetao protivnicima hrvatsko-ugarskoga prijateljstva. Po Vukoviću je Narodna stranka tek nakon banskoga imenovanja grofa KhuenaHéderváryja prestala s protumađarskim djelovanjem, iako ono još postoji iz prikrajka. Banu Khuen-Héderváryju je teškom mukom uspjelo zakočiti njihov rad, ali ukinuti ga nije mogao. Znajući da je protumađarska stranka u Hrvatskoj jednom već srušila vladu odanu Ugarskoj, lani su s istim ciljem planirani prosvjedi i nemiri, navodno s ciljem da se u Hrvatskoj uspostavi zakoniti poredak, no stvarni je cilj bio rušenje mađarske vlasti. Opstrukcija u mađarskom parlamentu im je dala dobru prigodu za to. Protivnici mađarskoga naroda i mađarske države požurili su pomoći pokretima usmjerenima protiv Mađara u Hrvatskoj. ${ }^{66}$

Poslije narečenoga je prešao na najosjetljivije pitanje naših odnosa, naime, na pitanje jezika. Što je neka nacija manja, to je ljubomornija na svoj jezik... Sukladno članku 57. Nagodbe hrvatski jezik je službeni jezik u svim državnim poslovima... To je naše teritorijalno pravo, pa se važeći zakoni ne poštuju ako se u bilo kojem segmentu u Hrvatskoj zapostavlja hrvatski jezik. Sukladno zakonu hrvatski je jedini zakoniti državni jezik $i$ u pitanju mađarskih državnih željeznica, šumarskih uprava $i$ stranih putovnica. Ne prihvaćam obrazloženje da su državne željeznice mađarsko privatno poduzeće, pa se stoga na njih ne odnose odredbe nagodbenoga članka 57.67 Zastupnik Kovačević izrazio je žaljenje što se sporazumijevanje između Hrvata i Mađara provodi na stranom (njemačkom) jeziku, pa se zauzeo za to da mađarski u Hrvatskoj bude barem poznat $u$ onolikoj mjeri kako je to slučaj s njemačkim. Po njemu je narušavanju mađarsko-hrvatskih odnosa pridonijelo i odbijanje oporbe da izglasa povjerenje ministru predsjedniku Khuen-Héderváryju. Njega se ovdje pogrdno naziva 'graničarom' kako u ovom domu, tako i u tisku. Poštovana oporba ne zna kako smiješna biva pred Hrvatima kad naziv graničar rabi kao pogrdu. Graničari su toljećima branili mađarske granice od vanjskih neprijatelja. Khuen-Héderváry nije bio graničar, ali su bila dva graničara među žrtvama borbe za slobodu 1848. godine: Damjanić i Knezić. ${ }^{68}$

65 Isto, str. 290.

66 Isto, str. 293.

67 Isto.

68 Kovačević je ovom izjavom upozorio svoje mađarske kolege da su s područja Hrvatske vojne krajine potjecali i kao graničari služili Jovan Damjanić (Damjanich János, rođen u Stazi, općina Sunja 1804.) i Karlo Knezić (Knezich Károly, rođen u Velikom Grđevcu 1808.) dvojica od trinaest generala mađarskoga domobranstva osuđenih na smrt vješanjem 1849. godine. Riječ je, dakle, o osobama koje se smatraju najvećim junacima nacionalne povijesti. (Kemény, G. 
„Dežurni kritičar” ugarske vlade u svezi s hrvatskim pitanjem Géza Polónyi na zasjednju 28. lipnja 1904. reagirajući na Kovačevićevo izlaganje kazao je da se iz njegovih riječi dade iščitati da mađarska oporba ne prihvaća grofa KhuenaHéderváryja za mađarskoga premijera budući da je pripadnik hrvatskoga naroda. Ja nisam načisto s geneologijom, ali koliko sam čitao bivši ministar predsjednik ne pripada hrvatskome narodu ni s naslova prezimena Khuen, a još manje Héderváry. Koliko je meni poznato sadašnji ministar kraljev personal dosad nije reklamirao pripadnost hrvatskoj naciji, a usto ima mađarski indigenat i mađarsko državljanstvo i to kao pripadnik mađarskoga naroda. Mi nismo glasovali za njegovu vladu, ali ne zato što je on Hrvat, jer to i nije, nego zbog njegove politike. ${ }^{69}$ Kritizirao je KhuenHéderváryjevu politiku tvrdeći da on u Hrvatskoj mađarskome imenu nije stekao ni slavu. ni ponos, ni simpatije, nego nemjerljivi stupanj mržnje, koji će moći nestati tek nakon više desetljeća. To nije učinjeno radi promicanja mađarske nacionalne ideje, nego isključivo radi austrijske carske dinastičke politike. Okrenuo je protiv nas sve Hrvate (tako je!). Kada je u priobalju, u Šibeniku con amore teklo prikupljanje novčanih prinosa u službi protumađarske promidžbe, kadaje na Trsatu održan sastanak radi oživljavanja jugoslavenske ideje o kojemu sam u vrijeme njegova banovanja progovorio ovdje u ovome domu, kada su na riječkome području s talijanskim zastupnicima - ako se dobro sjećam i Bianchini je bio tamo - planirali urotu protiv Ugarske, tada je već tamo bio i grof Khuen-Héderváry. Te su se stvari dogodile uz njegovo znanje. Nikada ništa nije poduzeo da se spriječi biskup Strossmayer, ili pak ove zloporabe... ${ }^{70}$

U nastavku je kazao da grofa Khuena-Héderváryja kao čovjeka poštuje, a onda ga je nadugo i naširoko optužio da je u austrijskom interesu vodio politiku podjele između Hrvata i Mađara. Zapitao je i kako su to hrvatski studenti dobili dozvolu polagati državni ispit na hrvatskome jeziku, pa je ta diploma postala jednakovrijedna austrijskoj. Nije mu bilo jasno ni kako je autonomna hrvatska vlada uspjela Beču podastrijeti molbu za izdavanje diplome o položenom državnom ispitu, iako bi banska vlada s Austrijom mogla komunicirati samo preko ugarskoga ministra predsjednika. Zapitao se i kako to da bečki i zagrebački rektor komuniciraju kao stari prijatelji „a radi se o dvije različite zemlje”. Zamjerio je Hrvatskoj da Srbima ne daje ni ona prava koja Ugarska osigurava priradnicima svih narodnosti, kao i da u Hrvatskoj uz panslavizam djeluje i jaka austrijska struja. To sve je toliko snažno da Hrvati radije recipiraju austrijsko kazneno pravo samo zato da ono ne bi sličilo mađarskome. ${ }^{71}$

Na ove je objede ministar Khuen-Héderváry kazao da se mora osvrnuti na dio govora narečenoga zastupnika ne samo zato jer je to dužan prema samome sebi, nego i zbog funkcije koju obnaša, ali i obveze prema domu i cijelome narodu. Istaknuo je da bi bio nedostojan dalje ostati „ovdje” u slučaju da zastupnik Polónyi uspije dokazati svoje objede. Prvo je zabavljao cijenjeni dom etimologijom pojma graničar,

Gábor: Iratok a nemzetiségi kérdés történetéhez Magyarországon a dualizmus korában. IV., str. 293.).

69 Kemény, G. Gábor: Iratok a nemzetiségi kérdés történetéhez Magyarországon a dualizmus korában. IV., str. 293.

70 Isto, str. 306-307.

71 Isto, str. 307. 
a potom mojim rodoslovljem. Ja ne želim time zamarati dom, nego samo naglašavam da sam se uvijek $i$ svugdje gdje sam boravio izjašnjavao kao pripadnik mađarskoga naroda. (Živio, na desnici.) Nisam to napravio samo ovdje, nego i u Hrvatskoj. (Živio, na desnici.) Ali to nije isključivalo da poslove i interese koji su mi bili povjereni u duhu zakona ne zastupam i u interesu Hrvatske (odobravanje na desnici.) ${ }^{72}$ Kazao je da nije graničar u smislu u kojemu ga se pokušalo predstaviti, dakle, da bude odbojan Mađarima. Odbacio je i tvrdnje da je eksponent bečke politike i da je sprječavao provedbu mađarskih nacionalnih ciljeva. $\mathrm{Na}$ optužbu da je ministar predsjednik barun Dezső Bánffy bio spreman odstupiti uviđajući koliko je politika hrvatskoga bana štetna, grof Khuen-Héderváry je rekao da je to sada čuo prvi put. Poznavajući Bánffyjev izravni način komunikacije siguran je da bi on bio prvi komu bi on to dao do znanja. Hrabro mogu izjaviti da kada sam ja bio u situaciji podnijeti ostavku premijeru barunu Dezsöu Bánffyju, onda ju on nije prihvatio, nego me je zamolio da ostanem na dužnosti. Mislim da sam do zadnjega trena uživao njegovo ne samo političko, nego i osobno povjerenje. Upravo zato sam iznenađen s ovdje iznesenim tvrdnjama- kazao je grof Khuen-Héderváry. ${ }^{73} \mathrm{Na}$ koncu je objedu da je plod njegova vladanja Hrvatskom raspirivanje mržnje između Hrvata i Mađara ocijenio napadom osobne naravi. Da je to bilo tako, onda ne bi većina zastupnika hrvatskoga naroda tijekom tih dvadeset godina prihvatila da temeljna načela odnosa s mađarskim narodom počivaju na Zak. članku XXX. iz 1868. i to unatočsvim teškoćama i objedama. Kada govorimo o razmišljanju i odnosima jednoga cijeloga naroda onda bismo u biti pred očima trebali imati upravo ovu većinu zastupnika hrvatskoga naroda, a ne da o njima sudimo na temelju sporadičnih izgreda, koji doista žaloste, a kojih sam i osobno bio svjedokom te potvrdujem da su u zadnje vrijeme u porastu. Razlog njima nije politički, nego financijski. ${ }^{74}$ Bivši ban nastavio je braniti svoju politiku, ali i Hrvate. G. zastupnik je kazao da je u Hrvatskoj osramoćen mađarski narod i zastava. No, nije li većina Hrvata stala u obranu mađarske zastave, da o hrvatskoj vladi i ne govorim, jer je ona to dužna bila napraviti... Iduća zastupnikova optužnica protiv hrvatskoga naroda i hrvatske vlade je ta da je ona služila stranim interesima omogućivši studentima koji su završili hrvatski fakultet da budu odgajani u Austriji. Na to mogu odgovoriti da niti u moje vrijeme, a niti sada to nije tražila ni hrvatska vlada, a niti pak hrvatski fakultet. (Tako je! - na desnici.) Nego se stvar dogodila tako da su u Dalmaciji hrvatska mladež, njihovi roditelji te javnost zahtijevali da se radi olakšavanja studiranja tamošnje mladeži njima omogući učenje na hrvatskom sveučilištu. Austrijska vlada sve do sada to nije dopuštala te nije ni priznavala tamo položene ispite kao temelj za stupanje u državnu službu, što je bilo predmetom stalnih pritužaba. Unutarnji odnosi te potreba za obrazovanjem dalmatinske mladeži naveli su austrijsku vladu da sama dade ove olakšice Dalmatincima koji u Hrvatskoj završe pravni fakultet, a bez kojega nije moguće njihovo zapošljavanje u javnim službama... Odbacujem optužbe da je Hrvatska tražila savez s Austrijom na štetu mađarske države

72 Dnevnik Zastupničkog doma. (Képviselőházi Napló), 1901.-1906., XXVI. 110-114. 1., str. 310311.

73 Isto, str. 311-312.

74 Isto. 
i to ne činim u ime hrvatske vlade, nego u ime hrvatske javnosti. To se nije dogodilo. (Tako je! - na desnici.) Da bih g. zastupnika ipak upoznao s prilikama u Hrvatskoj gdje sam tako dugo stajao na čelu poslova, želim pojasniti i to zašto se tamo i danas primijenjuje austrijski kazneni zakon. Hrvatska vlada naime, kani preuzeti mađarski kazneni zakon, ali kako i njemu slijedi stanovita revizija, stoga se čeka provedba te reforme. (Odobravanje na desnici.) ${ }^{75} \mathrm{I}$ napokon je grof Khuen-Héderváry stao $\mathrm{u}$ obranu hrvatskoga svećenstva jer su govornici iz izlaganja zastupnika Kovačevića istrgnuli neke rečenice te im pridali drugo značenje. Kraljev personal je bivšega velikog župana zagrebačkoga Kovačevića nazvao ne samo političkim, nego i osobnim prijateljem koji je u domu govorio izravno i hrabro kao $i$ u Hrvatskom saboru. Odbacio je tvrdnje zastupnika Polónyija da Hrvati s mržnjom gledaju na Mađare. Izravne riječi i tamo rado saslušaju. Mislim da nikada nije dobro govoriti uopćeno, a u političkim stvarima je to štetno, pa je i zastupnik Kovačević pogriješio govoreći tako o hrvatskom svećenstvu, premda dijelom ima istine u onome što je rekao... Zboreći o mojoj odgovornosti glede tvrdnje da su hrvatski biskupi protivnici mađarske države mogu kazati da sam osobno kandidirao dio njih, pa za njih mogu $i$ sada preuzeti odgovornost. (Odobravanje.) Posebno to vrijedi za zagrebačkoga nadbiskupa koga sam osobno predložio na tu čast i koga poznajem iz vremena kada je bio senjski biskup. Nikada njegovo političko držanje nije davalo povoda ni za najmanju zabrinutost, dapače i u teškim pitanjima u svezi s riječkom biskupijom nije uzrokovao nikakove poteškoće niti hrvatskoj a niti mađarskoj vladi. ${ }^{76}$ Objašnjavao je da su se hrvatski biskupi gdjekad vodili politiku usmjerenu protiv Mađarske, ali upravo je nadbiskup Posilović prošloga prosinca ili u siječnju ove godine okružnicom pozvao svećenstvo da prestane politizirati $s$ propovjedaonice. ${ }^{77}$ Ministar Khuen-Héderváry još je odlučnije nastupio glede optužaba da su nemiri u Hrvatskoj 1903. bili financirani iz Austrije. Glede ove optužbe držim se obveznim stati u zaštitu ne samo hrvatske vlade $i$ Hrvatske narodne stranke, nego i cijeloga hrvatskoga naroda ${ }^{78}$ Objasnio je da su iz Dalmacije općinama doista stigle takove pisane obavijesti, ali one ne dokazuju da se radilo o austrijskim novcima, nego samo to da se radilo o stranim novcima. Tadašnja vlada nije ostala nijema, nego je na prijepise dalmatinskih općina i gradova, uz suradnju mađarskoga Ministarskoga vijeáa poduzela mjere i kod austrijske vlade. Međutim, odbacujem tvrdnju da je hrvatski narod znao za strani novac i to da takav strani novac vodi njihovu politiku. Da mu je to bilo poznato, tako nešto sigurno ne bi otrpio. Naime, dio hrvatskoga naroda je pogrešno informiran, pa je mislio da postupa domoljubno, iako je pao pod strani utjecaj. ${ }^{79} \mathrm{Na}$ koncu izlaganja pohvalio se da je iz Hrvatske nestala svaka stranka i svaki trag politike koju je g. zastupnik opisao, a koja bi se nalazila pod austrijskim utjecajem. Nestao je i spomen na zadnjega graničara koji bi možda nju želio vratiti. (Odobravanje na desnici.) $)^{80}$

Rasprava o Hrvatskoj nastavljena je i 23. srpnja 1904. kada je Béla Komjáthy

75 Isto.

76 Isto, str. 313-314.

77 Isto, str. 314.

78 Isto.

79 Isto.

80 Isto. 
istaknuo da smatra potrebnim što više razgovarati o hrvatsko-mađarskim odnosima, a ne ih pomesti pod sag. Naveo je da se on i njegova oporbena stranka (Stranka neovisnosti i 1848.) zauzimaju za pridobivanje ljubavi i simpatija hrvatskoga naroda, a misli da je to želja i svih zastupnika u parlamentu koji također Hrvate smatraju bratskim narodom. Spomenuo je, međutim, da i sam Stjepan Kovačević drži međusobne odnose zategnutima. Istaknuo je da su Mađari uvijek željeli da se Hrvati ne osjećaju manjinom kao Slovaci ili Rusini, pa su stoga Hrvatima sveudilj pomagali da razvijaju svoj nacionalni identitet. Ali se hrvatska nacionalna ideja suprotstavlja mađarskoj državnoj ideji, a tu Mađari nisu skloni nikomu popuštati. Prava bratska ljubav vodila je Mađare u sklapanju nagodbe, pa su hrvatskoj braći ponudili neka napišu sve što žele i sve su im to dali. To je prihvatila ne samo mađarska vlada, nego i oporba. Zbog toga Béla Komjáthy zaključuje da je nagodba u svemu značila ostvarenje hrvatske volje, dok je Mađarima bilo dostatno samo osigurati da se u njoj jamči državno jedinstvo. Međutim, po njemu Hrvati nisu pristupili nagodbi s iskrenim čuvstvima, nego $s$ nepovjerenjem $i$ separatističkim nastojanjima. ${ }^{81} \mathrm{Za}$ to, kao i za svekoliko stanje i nemire u Hrvatskoj je, među inima optužio i bivšega bana KhuenaHéderváryja. Predbacio mu je i da je njegov stranački kolega i privrženik (Josip Pliverić) bio čovjek koji je 25 godina naučavao i bunio protiv mađarske državne ideje, a usto je - volio bih neka me demantira - jednom zamalo bio imenovan pročelnikom pravosudne uprave, što je spriječeno zahvaljujući pozornosti Ministarskoga vijeća. I kod svećeničkih imenovanja je rastao broj onih koji su tajno, a kada je trebalo $i$ javno neprijateljski nastupali prema mađarskoj državnoj ideji. Gospodin ministar, a tadašnji ban želio je stvoriti privid da je u Hrvatskoj sve u redu. a ta se slika stvarala iz saborskih spisa. Međutim, saborski poslovnikje sadržavao takova pr avila koja su onemogućavala reći ono što su zastupnici doista mislili. Rasprave su bile ograničene na tri dana, predsjednik Sabora mogao je isključiti zastupnika na 60 dana, dakle sve što je g. ministar napravio nije bilo pogodno da pobudi simpatije prema Mađarima. U pogrešnost te politike se $i$ osobno uvjerio 1895. u kraljevoj nazočnosti. ${ }^{82}$ Ministar kraljev personal je na izlaganje odgovorio da ne želi reagirati na sve optužbe, ali se radi utvrđivanja povijesne istine na neke stvari ipak mora reflektirati. Kazao je da je 1883. došlo do ozbiljnih političkih sukoba između Hrvatske i Ugarske kao rezultat unutarnjeg nezadovoljstva. Tada je provedeno sjedinjenje Vojne krajine s Hrvatskom, postojali su snažni čimbenici kojima to sjedinjenje nije bilo po volji, pa je tadašnja hrvatska oporba u biti poslužila interesima tih snaga. Po njemu to nije bio jedan promišljeni hrvatski nacionalni pokret, nego izvana inscenirana pobuna. Kao što je branio i druge svoje suradnike Hrvate, tako je stao i u obranu Josipa Pliverića kazujući da on kao znanstvenik ima pravo na svoje mišljenje i on ga ne želi dovesti u pitanje čak i ako je ono različito od onoga koje proizlazi iz mađarskoga važećega zakona. No, kazao je da narečeni zastupnik nikada nije spominjan kao kandidat za bilo koju odgovornu političku funkciju. Osim toga je na mjestu pročelnika pravosudne

81 D 1904 júl. 23 Komjáthy Béla és Kovácsevics István felszólalásai, gr. Khuen-Héderváry Károly uralkodó személye körüli miniszter válasza a horvát kérdés tárgyában az 1904. évi költségvetési vitában. U: Kemény G. Gábor, op. cit. IV., str. 316. Dnevnik Zastupničkog moma (Képv. Napló), 1901-1906, XXVII., str. 229-240.

82 Isto, str. 324-325. 
uprave tijekom 20 godina moga djelovanja u Hrvatskoj cijelo vrijeme stajao jedan čovjek i nikada nije bilo riječi o njegovu zamjenjivanju ${ }^{83}$ Odbacio je optužbe da su konstruirani propisi s ciljem onemogućavanja sloboda govora u saboru (premda je poslovnik sadržavao stroge odredbe) i slobode oporbenoga organiziranja i izbora. Odbacio je i tvrdnje da u Hrvatskoj više nema snaga na koje bi Ugarska mogla računati. Tvrdim da će nakon stanovita vremena mlađi dio današnjega naraštaja uvidjeti ono što smo mi stariji spoznali, naime, da veze između Ugarske i Hrvatske znače prednost ne samo za Mađarsku, već i za Hrvatsku. (Tako je! - na desnici). Zato ja jamčim za tu mladež i naraštaj koji je sazrio u vrijeme dok sam ja tamo imao sreću služiti. ${ }^{84}$ Dodao je kako je važno da i Hrvati vide da mogu računati na nas. Odbacio je zastupnikov prijedlog da se i na silu pokuša privoljeti Hrvate na odanost, ako se to ne bude moglo postići lijepim riječima. Ja vjerujem, a i mađarska povijest to svjedoči, da je jedino $i$ isključivo zakonitim putem moguće osigurati interese koje ugarski parlament itekako mora imati pred očima i to ne samo u korist mađarskoga, nego i hrvatskoga naroda koji s njime živi u državnoj zajednici. ${ }^{85}$ Njegov je govor pozdravljen povicima ,živio" na desnici i u sredini sabornice.

Stjepan Kovačević se potom javio za riječ i kazao da ne dijeli optimizam ministra kraljevskoga peronala da je „već sada” moguće postići približavanje između Hrvata i Mađara, nego je po njemu potrebno raditi na odgajanju jednoga novog naraštaja koji će biti spreman na suradnju. Rekao je da bi bio vrlo sretan da se obistine ministrove riječi, ali po njemu bi već u školama djecu u sasvim mladoj dobi trebalo odgajati i politički. Reagirao je i na govor zastupnika Béle Komjáthyja u svezi s hrvatskim Srbima ističući da u Hrvatskoj, točnije u Slavoniji postoji nekoliko općina koje nastanjuje čisto mađarsko pučanstvo. S njima Hrvati nikada nisu imali nikakovih problema. Imaju škole na mađarskom jeziku, bogoslužje - ako su protestanti obavljaju ga na mađarskom jeziku... Izvolite samo prolistati Magyar Szó. U njemu ćete pronaći napis tordinačkoga kalvinističkoga svećenika Eleka Kuliffaya koji kaže da Hrvati - niti narod, a niti vlasti -, nikada nisu širili mržnju prema Mađarima, nego su s njima uvijek živjeli u najboljoj slozi. ${ }^{86}$

Grof Karlo Khuen-Héderváry se u svome drugome inauguralnome premijerskom govoru održanome u Domu velikaša 24. siječnja 1910. osvrnuo na hrvatsko pitanje kazavši da je temeljni kamen naših državnopravnih odnosa Zak. članak II. iz 1723. nazvan Pragmatičkom sankcijom... Glede Hrvatske i Slavonije nastojat ćemo naše odnose riješiti prema načelima pravednosti, uz potpunu zaštitu interesa mađarske države i zakona koji reguliraju te odnose... Čvrsto smo uvjereni da su teški potresi u našemu društvu u zadnjemu desetljeću uglavnom posljedica činjenice da reforme državnoga sustava nisu pratile društveni i gospodarski razvoj države. ${ }^{87}$ Želio je za svoj mandat dobiti potporu hrvatskih delegata, ali je biskup Antun Bauer rekao da

83 Isto.

84 Isto, str. 328.

85 Isto, str. 329.

86 Isto.

87 Dnevnik Doma velikaša (Főrendiházi Napló) 1906-1911. III. sv., str. 168-170. Priopćava Kemény, G. Gábor: Iratok a nemzetiségi kérdés történetéhez Magyarországon a dualizmus korában, V. 1906-1911., str. 318-320. 
će stajalište hrvatskih zastupnika prema ugarskoj vladi zbog sukoba koji su između Ugarske i Kraljevine Hrvatske nastali u svezi sa željezničkom pragmatikom te drugim spornim pitanjima u svezi s nagodbom, ovisiti od poštovanja zakonom zajamčenih prava Hrvatske i vraćanja njezine ustavnosti. ${ }^{88}$ Zbog toga je izjavio da će Hrvati kod glasovanja o povjerenju vladi biti suzdržani. ${ }^{89}$ Premijer je kasnije kazao da smatra jednom od svojih prvih zadaća obnoviti suradnju s Hrvatima oko autonomnih poslova koja „već tri godine ne postoji”. Stoga je pokrenuo razgovore i pregovore koji su urodili plodom. Tako je osigurana suradnja između vladajuće koalicije i hrvatske stranke, pa sukladno dogovoru mađarska strana pristaje podržati buduću novoimenovanu hrvatsku vladu sastavljenu od provjerenih unionista te će pružanjem stalne financijske pomoći osigurati nesmetano djelovanje Hrvatskoga sabora. Ministarsko vijeće je sa zadovoljstvom primilo na znanje postizanje dogovora te ga je radosno odobrilo. ${ }^{90}$

O hrvatskom pitanju grof Khuen Héderváry progovorio je kao premijer i u odgovoru na zastupničko pitanje oporbenjaka grofa Tivadara Batthyánya (zastupnika Juszthove stranke iz Szekszárda) na 291. zemaljskoj sjednici Zastupničkog doma u petak 17. studenoga 1911. Tada je grof Batthyány optužio Hrvatsku da vodi očiglednu trialističku politiku, na što je bivši ban kazao da u Hrvatskoj trijalizam nije vladajuće stajalište, te da je unatoč svih nerazjašnjenih pitanja ,ipak došlo do potpunoga mira“, dakle banska vlada je svoj posao dobro obavila. Opet je uzeo u zaštitu svoga prijatelja Nikolu Tomašića odbacujući oporbene optužbe protiv bana, a preko njega dakako i protiv njega samoga ${ }^{91} \mathrm{Na}$ spomenutoj sjednici se grof Khuen Héderváry osvrnuo i na asimilacijske tendencije Julijanske akcije koju je osudio pred cijelim Zastupničkim domom, kao i na pitanje tzv. mađarskih škola u Hrvatskoj o čemu je rekao: Bit stvari je u tome da su narečene škole osnovane onako i na onim temeljima na kojima su njihovi osnivači to molili. Julijanska udruga je primjerice tražila osnivanje radi očuvanja mađarskoga identiteta, pa joj je ta djelatnost $i$ odobrena.$^{92}$ Kazao je da ukoliko one iziđu izvan okvira navedenih u dozvoli, onda mogu nastupiti komplikacije i političke situacije koji nikako nisu poželjne po Mađarsku. ${ }^{93}$ Istaknuo je da s velikom pozornošću prati događaje oko ovih škola i zaključuje da „nažalost” one djeluju mimo nakana njihovih osnivača, bez obzira radi li se o mađarskim državnim željeznicama, Julijanskoj udruzi ili drugome osnivaču. Škole su osnovane za školovanje mađarske

88 Predsjedavajući Sándor Gál naknadno je reagirao na biskupov govor kazavši da je prema stenografskim bilješkama zastupnik Antun Bauer spomenuo Hrvatsko Kraljevstvo, a prema nagodbi postoji državna zajednica Ugarske i Trojednice koje čine jedno kraljevstvo. Dakle, nema Kraljevine Hrvatske pa stoga zastupniku naknadno izriče opomenu, što su nazočni zastupnici popratili glasnim odobravanjem.

89 Dnevnik Zastupničkog doma (Képviselőházi Napló) 1906. XXVI., str. 144-146. Priopćava Kemény, G. Gábor: Iratok a nemzetiségi kérdés történetéhez Magyarországon a dualizmus korában, V. 1906-1911., str. 320-321.

90 Vlada/Ministarsko vijeće (Minisztertanács - MT), 1910:4/2. Priopćava Kemény, G. Gábor: Iratok a nemzetiségi kérdés történetéhez Magyarországon a dualizmus korában, V. 1906-1911., str. 329.

91 Dnevnik Zastupničkoga doma (Képviselőházi Napló), 1910-15. XI., str. 243-245.

92 Dnevnik Zastupničkoga doma (Képviselöházi Napló), 1910-15. XII. 291. sjednica u petak 17. studenoga 1911., str. 267-269.

93 Isto, str. 273. 
djece, ali su nakon njihova otvaranja tamošnji nastavnici, ili ne znam, drugi čimbenici, pored toga cilja, sebi zacrtali i provođenje mađarizacije te su u škole uključili i djecu kojoj mađarski nije materinski jezik. To se dogodilo na zaista puno mjesta i time je naravno tamo proizvelo otpor čemu se ne trebamo čuditi, jer ako pripadnici mađarskog naroda žele živjeti i ćutiti se kao Mađari, onda je isto tako opravdano da i pripadnici hrvatskoga naroda hoće živjeti $i$ ćutiti se Hrvatima te da ne žele da njihovi sinovi budu odnarođeni. Ovakove su okolnosti bile razlogom da je tamo došlo do stanovitih neugodnosti na čijemu otklanjanju djeluje ne samo hrvatska vlada, nego, koliko mi je poznato - putem hrvatskoga bana - $i$ mađarska vlada s ciljem da se popravi šteta i da ove škole obavljaju svoju osnovnu djelatnost. Dakle trebaju se ukloniti zloporabe, pa će istoga sata prestati i pritužbe iz Hrvatske, te ove škole više ne će izazivati odijum u tamošnjoj javnosti. Pozivam osnivače tih škola da u obavljanju svoje zadaće ostanu kod svoje osnovne namjene, pa će tada biti mir...94.

Pozvao je i zastupnike da pažljivo postupaju s pritužbama Mađara iz Hrvatske jer se i on sam osvjedočio da su se neki od "naše tamo živuće mađarske braće” neopravdano žalili zbog zlostavljanja hrvatskih vlasti. Po njemu sve te tvrdnje nisu uvijek istinite, iza njih stoje i privatni interesi. No, u slučaju opravdane pritužbe će i ban i ugarska vlada zaštititi ugrožene. ${ }^{95}$ Izrazio je nadu da će $s$ vremenom nestati ovi problemi s kojima se Hrvatska sada suočava i to ne samo u našemu interesu, nego $i$ u interesu Hrvatske s kojom nas na suživot upućuju povijesne i zemljopisne datosti, postojeće stanje i gospodarski interesi, a to su istodobno i naši interesi. (Odobravanje na desnici). Ukoliko uspijemo ostvariti mir, onda ćemo učiniti uslugu objema stranama, a ojačat ćemo i snagu države što nam je prvotna obveza. ${ }^{96}$

\section{ZAKLJUС̆AK}

Što ostaje iza grofa Karla Khuen-Hedervaryja? U Hrvatskoj prevladava negativna slika o njegovoj ostavini: „vladao je nasilno, koristeći se 'izbornom geometrijom' (prekrajanjem izbornih jedinica, reguliranjem izbornih redova njemu po volji), vršeći pritisak na činovništvo i državni aparat", potiskivao je hrvatske nacionalne težnje, a promicao mađarizaciju i davao povlastice Srbima. Poslije reformi Ivana Mažuranića Khuen-Héderváry je od 1885. do 1887. godine preuredio sudstvo i upravu stavljajući ih pod veći utjecaj bana, za njegova je vladanja sužena sloboda javnog izražavanja, provedena je reorganizacija županija (Zakonom o ustroju županija i uređenju uprave u županijah $i$ kotarih Hrvatska je 1886. podijeljena na osam županija sa širokim ovlastima banu podređenih župana), te je 1888. potvrdio novi izborni zakon kojim je pravo glasa imalo samo dva posto najbogatijeg stanovništva. Pri vrednovanaju njegove uloge valja znati i da je ban bio aristokrat, vladao je slično njegovom staležu pripadajućim mađarskim grofovima na čelu ugarske vlade, dakle, ne baš po današnjim demokratskim načelima. Zato je i prema političkim oponentima (pravaši, Stjepan Radić) postupao kao prema preprekama koje stoje na putu koji si je zacrtao. Politički

94 Isto, str. 265.

95 Isto, str. 266.

96 Isto. 
dakle, on nije pridonio Hrvatskoj, ali jest glede gospodarstva, prometa, kulture, urbanizacije. O narečenim doprinosima smo pisali, osim urbanizacije, u vezi s kojom treba spomenuti da je u Zagrebu za njegova vladanja 1893. godine svoj današnji oblik dobio perivoj Zrinjevac, a 1895. godine nastao je i Trg Franje Josipa I (danas Trg kralja Tomislava), čiji je položaj određen Khuen-Héderváryajevom odlukom o darivanju Umjetničkog paviljona 1896. godine.

Banov prinos prepoznala je čak i oporba, pa je dobio pohvale za svoj rad, imenovan je počasnim građaninom Zagreba, a po njemu su prozvani i trgovi u Zagrebu (od 1896. do 1918. kada je preimenovan u Trg 29. listopada 1918., od 1930. to je Wilsonov trg, od 1944. Trg II, a od 1947. Rooseveltov trg) ${ }^{97}$ i Osijeku (današnji središnji Trg Ante Starčevića nosio je banovo ime do 1918.). O vrednovanju njegovih zasluga Stjepan Kovačević je u Ugarskom saboru kazao: Poznato je da je Karlovac najoporbeniji i najnemirniji grad u Hrvatskoj s isključivo oporbenim zastupničkim tijelom i gradonačelnikom, pa je čak i takav grad kolektivno zahvalio banu zato što je omogućio njegov napredak. Da je Khuen-Héderváry provodio nasilje u Hrvatskoj $i$ vladao kao satrap onda jamačno ne bi dobio kolektivno priznanje toga grada. ${ }^{98}$

\section{LITERATURA}

1. A horvát kérdés az 1904. évi költségvetés vitájában, A 1904 jún. 27. Kovácsevics István horvát-szlavon képviselő beszéde a horvát kérdésről az 1904. évi költségvetési vitában. U: Kemény, G. Gábor: Iratok a nemzetiségi kérdés történetéhez Magyarországon a dualizmus korában. IV.

2. Ács, Zoltán, Nemzetiségek a történelmi Magyarországon. Az 1984-ben megjelent nemzetiségek a történelmi Magyarországon címủ kötet átdologozott kiadása. Kossuth Könyvkiadó, 1996.

3. Artuković, Mato, Srbi u Hrvatskoj (Khuenovo doba). Bibliotheca Croatica: Slavonica, Sirmiensia et Baranyensia; knj. 2., Slavonski Brod, 2001.

4. Bajza, József, A horvát kérdés. Válogatott tanulmányok. Királyi Magyar Egyetemi Nyomda. Budapest, 1941.

5. Balta, Ivan, Pravnopovijesni hrvatsko-mađarski odnosi od dualizma do propasti monarhije, s posebnim osvrtom po pitanjima obrazovanja, Zbornik radova Pravnog fakulteta u Splitu, god. 43, br. 3-4. (83), str. 361-375.

6. Bibó, István, Válogatott tanulmányok I-IV. I. kötet 1945-1949. Magvető Könyvkiadó. Budapest, 1986.

7. Čepulo, Dalibor, Ivan Mažuranić: liberalne reforme Hrvatskog sabora 1873.-1880. i srpska elita u Hrvatskoj. Dijalog povjesničara-istoričara: Herceg Novi, 1.-4. ožujka 2001. Ured.: Hans-Georg Fleck - Igor Graovac, Zaklada Friedrich Naumann, Zagreb, 2002.

8. Cipek, Tihomir i Matković, Stjepan (prir.), Programatski dokumenti hrvatskih političkih stranaka i skupina 1842-1914. Zagreb, 2006., str. 121-125.

9. D 1904 júl. 23 Komjáthy Béla és Kovácsevics István felszólalásai, gr. Khuen-Héderváry Károly uralkodó személye körüli miniszter válasza a horvát kérdés tárgyában az 1904. évi költségvetési vitában. U: Kemény G. Gábor op. cit. IV., str. 316. Dnevnik Zastupničkog moma (Képv. Napló), 1901-1906, XXVII., str. 229-240.

97 Jelena Stanić, Laura Šakaja, Lana Slavuj: Preimenovanja zagrebačkih ulica i trgova. U: Migracijske i etničke teme 25. Zagreb, 2009., br. 1-2., str. 89-124., str. 95. i 120.

98 Kemény, G. Gábor: Iratok a nemzetiségi kérdés történetéhez Magyarországon a dualizmus korában. IV., str. 293. 
10. Djela dra Ante Starčevića, izdaje Odbor Kluba Stranke prave, knj. III, Znanstvenopolitičke rasprave, Zagreb, 1894, pretisak, 1995., str. 315. Priopćava: Željko Holjevac, http://www.azoo.hr/images/izdanja/manjine/05.html (10. svibnja 2016.)

11. Dnevnik Doma velikaša (Főrendiházi Napló) 1906-1911. III. sv., str. 168-170. Priopćava Kemény, G. Gábor: Iratok a nemzetiségi kérdés történetéhez Magyarországon a dualizmus korában, V. 1906-1911., str. 318-320.

12. Dnevnik Zastupničkog doma (Képviselőházi Napló), 1906. XXVI., str. 160-162. I Kemény, G. Gábor: Iratok a nemzetiségi kérdés történetéhez Magyarországon a dualizmus korában

13. Dnevnik Zastupničkog doma (Képviselőházi Napló) 1906. XXVI. str. 144-146. Priopćava Kemény, G. Gábor: Iratok a nemzetiségi kérdés történetéhez Magyarországon a dualizmus korában

14. Dnevnik Zastupničkog doma (Képviselőházi Naplo), 1906., XXIII., str. 61-64. Kemény, G. Gábor: Iratok a nemzetiségi kérdés történetéhez Magyarországon a dualizmus korában.

15. Dnevnik Zastupničkog doma. (Képviselőházi Napló), 1901-1906., XXVI. 110-114. 1., str. 310-311.

16. Dnevnik Zastupničkoga doma (Képviselőházi Napló) 1901-1906., XVII.

17. Dnevnik Zastupničkog doma (Képviselőházi Napló, 1901-1906., XVIII.

18. Dnevnik Zastupničkoga doma (Képviselőházi Napló), 1910-15. XI., str. 243-245.

19. Dnevnik Zastupničkoga doma (Képviselőházi Napló), 1910-15. XII., 291. sjednica,17. studenoga 1911., str. 267-269.

20. Dobrovšak, Ljiljana, Židovi u banskoj Hrvatskoj u zbivanjima 1903.-1904., Časopis za suvremenu povijest, Zagreb, 2005., br. 3., str. 635-652.

21. Gróf Khuen-Héderváry családja. U: Vasárnapi Újság, 1903., 50. god., br. 27., str. 434435.

22. Gyurkovics, György, 1903. Grőf Khuen-Héderváry mint államférfi, és mint ember. U: Vasarnapi Újság, 1903., br. 30., str. 420.

23. Holjevac, Željko, Mađaroni i mađarizacija u Hrvatskoj između mita i zbilje u svjetlu hrvatsko-mađarskih odnosa u 19. stoljeću. U: Hrvati i manjine u Hrvatskoj: moderni identiteti. Četvrti hrvatski simpozij o nastavi povijesti. Agencija za odgoj i obrazovanje. Zagreb, 2014., http://www.azoo.hr/images/izdanja/manjine/05.html (20. rujna 2016.)

24. Holjevac, Željko, Pravo u službi nacionalnog pokreta: Josip Pliverić o pravnoj prirodi hrvatsko-ugarske 'državne zajednice' u doba dualizma. U: Marijana Marinović (ur.), Nacionalni pokret u Hrvatskoj u 19. stoljeću, Zagreb, 2008., str. 57-65.

25. Horvat, Josip, Politička povijest Hrvatske I., Zagreb, 1989., str. 251-252.

26. Hrvatski djaci pred sudom. Stenografski izvještaj o glavnoj razpravi proti hrvatskim sveučilištnim djacima obdržanoj pred kr. sudbenim stolom u Zagrebu dne 11-16. studenoga 1895. (Preštampano iz Obzora), Zagreb 1895., pretisak Zagreb 1995. Priopćava: Iveljić, Iskra, 2008., str. 591-592. http://www.sulinet.hu/oroksegtar/data/ magyarorszagi_nemzetisegek/nemetek/nemzetisegek_a_tortenelmi_magyarorszagon/ pages/014_a nemzetiseg_a_vilaghaboru_elott.htm (10. lipnja 2015.)

27. Iveljić, Iskra, Od uza Sudbenog stola do turneje po Rusiji, Nepoznata pisma Josipa

28. Henneberga iz 1894.-1897., Časopis za suvremenu povijest, vol. 40., no. 2(2008), str. 587-624.

29. Kemény, G. Gábor, Iratok a nemzetiségi kérdés történetéhez Magyarországon a dualizmus korában, III. 1900-1903.

30. Kemény, G. Gábor, Iratok a nemzetiségi kérdés történetéhez Magyarországon a dualizmus korában. IV. str. 293.

31. Kenyeres, Ágnes (főszerk.): Magyar életrajzi lexikon I. (A-K). Akadémiai Kiadó, Budapest, 1967. 
32. Kolar-Dimitrijević, Mira, Izidor Kršnjavi i simbolika zagrebačke Zlatne dvorane, Kolo, Zagreb, 2, 13., br. 5. http://www.matica.hr/kolo/401/Izidor\%20Kr\%C5\%A1njavi\%20 i\%20simbolika\%20zagreba\%C4\%8Dke\%20Zlatne\%20dvorane\%20 (10. lipnja 2016.)

33. Krestić, Vasilije, O nazivu jezika u prošlosti Hrvatske. Primljeno na II skupu Odelenja istorijskih nauka od 21. marta 1990., http://kovceg.tripod.com/vk_o_nazivu_jezika.htm (10. svibnja 2015.)

34. Kušlan, D.; Šuhaj, M., Spisi saborski sabora kraljevinah Dalmacije, Hrvatske i Slavonije od godine 1865-1867, Zagreb, 1962., knj. I.

35. Ministarsko vijeće (MT) 1897: XXXIV/11. Priopćava: Kemény, G. Gábor: Iratok a nemzetiségi kérdés történetéhez Magyarországon a dualizmus korában, III. 1900-1903., str. 615-617.

36. Narodne novine, LVII. br. 186. Zagreb, 15. VIII 1891. Priopćava: Gostl, Igor: Najveća predstava u Zagrebu, ABC, Zagreb, 1966.

37. Ostajmer, Branko, 2009. Khuen - ključna epizoda slavonskog regionalizma. In: Slavonija, Baranja i Srijem. Vrela europske civilizacije, sv. 1, ur. Božo Biškupić, Vesna Kusin, Branka Šulc, Zagreb, str. 390.-397.

38. Perić, Ivo, Hrvatski državni sabor 1848.-2000., (drugi svezak 1868.-1918.), Zagreb, 2000.

39. Polić, Martin, Ban Dragutin grof Khuen-Héderváry i njegovo doba, Zagreb, 1901.

40. Polić, Martin, Parlamentarna povijest Kraljevine Hrvatske, Slavonije i Dalmacije. Dio prvi, od godine 1860. do godine 1867., Zagreb, 1899.

41. Predsjednik Vlade (ME) 1898 - XVII - 1.686. Priopćava: Kemény, G. Gábor: Iratok a nemzetiségi kérdés történetéhez Magyarországon a dualizmus korában, III. 1900.-1903., Budapest, 1964.

42. Stanić, Jelena; Šakaja, Laura; Slavuj, Lana, Preimenovanja zagrebačkih ulica i trgova, Migracijske i etničke teme 25., Zagreb, 2009., br. 1-2., str. 89-124.

43. Šokčević, Dinko, Hrvati u očima Mađara, Mađari u očima Hrvata. Kako se u pogledu preko Drave mijenjala slika drugoga, Zagreb, 2006., str. 140-142.

44. Janjatović, V. B., 2003. Stjepan Radić. Progoni-zatvori-suđenja-ubojstvo (1889.-1928.), Zagreb, 2003.

45. Vlada/Ministarsko vijeće (Minisztertanács - MT), 1910:4/2. Priopćava Kemény, G. Gábor: Iratok a nemzetiségi kérdés történetéhez Magyarországon a dualizmus korában 
Summary

\section{VICEROY KARLO (KÁROLY) KHUEN-HÉDERVÁRY AND THE CROATS}

Viceroy Károly (Croatian historiography is sometimes referred to by the name of Karlo; Charles, and sometimes in the croatian language form of Dragutin) Count Khuen Héderváry is one of the most important and highest ranked individuals in Croatian-Hungarian history, a statesman who was twice honored with the Viceroy title (1883. - 1903.) and has been elected as the president of the Hungarian Government (June 27, 1903 - November 3, 1903 and January 17, 1910 - April 22, 1912).

He has marked Croatian history greatly at the turn of the 19th and 20th centuries, but in historiography and in folk consciousness he has been registered in a extremely negative way, often being accused for Magyarisation of Croatia.

As such, the Count Khuen-Héderváry became generally known in Croatia, although the vast majority of Croats don't not know anything else but the above mentioned stereotypes.

It is often argued that he was a foreigner, imposed from outside (Hungary), although he grew up and lived most of his life in Croatia. All his life he stood up for maintaining the Hungarian-Croatian state community and has promoted cooperation and coexistence between the two peoples, and also as a Viceroy he defended the rights of Croats.

In his thesis the author analyzes the political situation in Hungary and Croatia in the second half of the 19th century and early 20th century, and he presents the point of view of Viceroy Khuen-Hedervary and his role in the history of Croatian-Hungarian State.

Keywords: Croatian Viceroy and President of the Hungarian government, Viceroy Karlo Khuen Héderváry, Croatian-Hungarian state union, dualism, a national issue, the debate on the budget for the year 1904.

\section{Zusammenfassung}

\section{GROF KARLO (KÁROLY) KHUEN-HÉDERVÁRY UND DIE KROATIEN}

Ban Károly (in der kroatische Geschichtsschreibung auch unter dem Namen Karlo, Charles und der kroatischen Sprachform Dragutin bekannt) Graf Khuen Héderváry ist einer der bedeutendsten und höchsten Persönlichkeiten in der kroatischungarischen Geschichte, ein Staatsmann, der zweimal mit dem Titel Ban (1883 - 1903) geehrt und zum Präsidenten der ungarischen Regierung (27. Juni 1903 - 3. November 1903 und 17. Januar 1910 - 22. April 1912) gewählt wurde. Er hat die kroatische 
Geschichte um die Wende des 19. und 20. Jahrhunderts stark geprägt, dennoch ist er in der Geschichtsschreibung und im Volksbewußtsein äußerst negativ dargestellt und wird oft für die Magyarisierung Kroatiens angeklagt.

Die überwiegende Mehrheit der Kroaten weiß nicht viel über Graf KhuenHéderváry, obwohl die oben erwähnten Stereotype sehr wenig mit den historischen Tatsachen zu tun haben. Es wird oft behauptet, dass er ein Ausländer war, der von außen (von Ungarn) auferlegt wurde, obwohl er in Kroatien aufgewachsen ist und die Mehrheit seines Lebens hier verbracht hat. Sein ganzes Leben lang setzte er sich für die Aufrechterhaltung der ungarisch-kroatischen Staatsgemeinschaft ein und förderte die Kooperation und Koexistenz zwischen den beiden Völkern. Die kroatischen Rechte verteidigte er nicht nur als Ban sondern auch als der erste ungarsiche Minister.

In diesem Artikel analysiert der Autor die politische Situation in Ungarn und Kroatien in der zweiten Hälfte des 19. Jahrhunderts und am Anfang des 20. Jahrhunderts, stellt den Standpunkt des Grafen Khuen-Hedervary und seine Rolle in der Geschichte des kroatisch-ungarischen Staates dar.

Schlüsselwörter: Kroatischer Ban und Präsident der ungarischen Regierung, Graf Karlo Khuen Héderváry, kroatisch-ungarische Staatsunion, Dualismus, nationale Frage, Debatte über den Haushaltsplan für das Jahr 1904.

\section{Riassunto}

\section{IL CONTE KARLO (KÁROLY) KHUEN-HÉDERVÁRY ED I CROATI}

Una delle persone più note nella storia croata senza dubbio fu il bano Károly (Karlo, Dragutin) conte Khuen Héderváry, il quale appartiene al rango delle figure più significative e più altolocate nella storia croato-ungherese. Egli fu uno statista che per due decenni rivestì la prestigiosa carica di bano e per due volte anche quella di presidente del governo ungherese. A differenza del suo predecessore, il barone Josip Jelačić, con riguardo al quale la storiografia croata ha memoria soltanto delle caratteristiche buone, il conte Khuen Héderváry nella coscienza collettiva è rimasto impresso in una luce assai negativa quale personaggio storico che si spendeva per la magiarizzazione della Croazia. Di lui sovente non si sa altro al di fuori di tali stereotipi che non corrispondono propriamente ai fatti storici. Di frequente si pone in rilievo che fosse straniero, imposto dall'esterno (dall'Ungheria), benché fosse cresciuto ed avesse vissuto la maggiore parte della vita in Croazia. Si impegnava per il mantenimento della comunità statale magiaro-croata e promuoveva la cooperazione e la coesistenza dei due popoli; mentre rappresentava i diritti della Croazia non soltanto espletando la funzione di bano, bensì anche quale personale regio e primo ministro ungherese.

$\mathrm{Nel}$ presente lavoro analizziamo il contesto politico in Ungheria ed in Croazia nella seconda metà del XIX secolo ed agli inizi del XX secolo ed esponiamo le 
posizioni assunte dal conte Khuena-Héderváryja circa la questione croata.

Parole chiave: bano croato e presidente del governo ungherese conte Karlo Khuen Héderváry, comunità statale magiaro-croata, dualismo, questione nazionale, discussione sul bilancio per l'anno 1904. 
